Article

\title{
Assessment of Landscape Character and Absorptivity Based on Digital Terrain Model Analysis-Case Study of Jelenia Góra City in Poland
}

\author{
Grzegorz Budzik $^{1}\left(\mathbb{D}\right.$ and Piotr Krajewski ${ }^{2, *}$ (D) \\ 1 Department of Architecture, Wroclaw University of Science and Technology, 50-370 Wrocław, Poland; \\ grzegorz.budzik97@gmail.com \\ 2 Institute of Spatial Management, Wroclaw University of Environmental and Life Sciences, \\ 50-357 Wrocław, Poland \\ * Correspondence: piotr.krajewski@upwr.edu.pl
}

Citation: Budzik, G.; Krajewski, P. Assessment of Landscape Character and Absorptivity Based on Digital Terrain Model Analysis-Case Study of Jelenia Góra City in Poland. Sustainability 2021, 13, 7969. https:// doi.org/10.3390/su13147969

Academic Editor:

Alexandre B. Gonçalves

Received: 7 June 2021

Accepted: 13 July 2021

Published: 16 July 2021

Publisher's Note: MDPI stays neutral with regard to jurisdictional claims in published maps and institutional affiliations.

Copyright: (c) 2021 by the authors. Licensee MDPI, Basel, Switzerland. This article is an open access article distributed under the terms and conditions of the Creative Commons Attribution (CC BY) license (https:/ / creativecommons.org/licenses/by/ $4.0 /)$.

\begin{abstract}
In an era of significant growth in the availability of spatial data and continued advances in computing technologies, opportunities for new interpretations and solutions to the landscape research problems posed worldwide are emerging. This paper presents different possibilities of applying digital terrain model (DTM) data in research of various aspects of landscape. For this purpose, two different methods were proposed. The first was to identify a set of components of the Jelenia Góra city landscape character on the basis of the topographic position index and spatial distribution of land cover, while the second was to assess the landscape of Jelenia Góra city in terms of the possibility of adopting new elements, using the author's scenic absorptivity method. The results indicate the structure of the components of the landscape character of Jelenia Góra city together with its spatial distribution, which also allowed for the delineation of landscape units. The scenic absorptivity analysis showed that there are isolated areas within Jelenia Góra city that are capable of accommodating significant size elements that would not adversely affect the city landscape. In conclusion, DTM data are able to significantly improve research methods in landscape studies.
\end{abstract}

Keywords: digital terrain model; scenic absorptivity; landscape capacity; visual absorption capability; topographic position index; landform classification; landscape valorization; landscape characteristics

\section{Introduction}

The digital terrain model (DTM) is a numerical representation of a terrain surface created by a set of appropriately selected points lying on this surface and interpolation algorithms enabling its reconstruction in a specified area [1]. The interpolation algorithm makes it possible to determine the height $(Z)$ of any point, defined in the model area by a pair of plane coordinates (X and Y) [2]. DTM can be classified by the content of objects located on the land surface. The most commonly used terms include the digital elevation model (DEM) — which contains the elevation of the actual land surface (excluding land cover elements, such as buildings, structures, trees, and shrubs) [3-12] - and the digital situation (surface) model (DSM), representing the shape of the surface spanned by objects on the land surface (buildings, structures, trees, and shrubs) or directly on the terrain [2,13-15]. In this paper, DTM is understood as a general term for a set of terrain elevation data, without information on coverage or lack thereof. The terms DSM (for a model with land cover) and DEM (for a model without land cover) are used to denote information on the content of land cover elements in the model. In this sense, both terms constitute a DTM.

Both in the literature and among the tools available in the GIS environment, there are many products resulting from calculations using a DTM. It can be used for a multitude of purposes in a variety of fields, including hydrology [16-18], geomorphology [19], urban 
planning [20], architecture, archaeology, geology [21], telecommunications, agriculture, ecology, forestry, defense, security, tourism, and most importantly, landscape studies [22]. Research and assessment in this field of study are extremely challenging tasks for natural sciences, as they are fraught with subjectivity related to the intuitive nature of research methods. The complexity of issues, based on different scientific disciplines, contributes to this, which often leads to different, sometimes mutually exclusive, research results [22]. The digital terrain model makes it possible to objectivize parameters of landscape forms description and assessment, and also creates the possibility of the more objective assessment of landscape forms for both scientific and land use purposes [22]. Digital tools provide an opportunity to estimate the distribution of landscape forms of special value and indicate their spatial interrelationships, which contributes to the development of landscape and environmental protection analyses. It is theoretically possible to classify landscape forms based on the comparison of a number of geomorphometric indicators, such as slope, exposure, roughness, relief intensity, or peakiness [23]. All these indicators can be calculated from the DTM data. This proves to be extremely useful in landscape management. Geomorphometrical data can support comprehensive analyses, not only facilitating the understanding of landscape processes and landscape conditions, but above all providing the basis for conclusions in the context of landscape policy. Both the digital terrain model and the slope and exposure resulting from its calculations, in combination with a dataset containing, e.g., land cover information for different time periods, can be used to study landscape changes [24]. Topographic conditions, which can be described by a digital terrain model, significantly determine the accessibility of an area, which affects the probability of, e.g., construction investments being carried out. Thus, by understanding that the landscape changes are largely dictated by land transformations in terms of development, they can be considered as a natural driving force of landscape transformation, which over the years has proven to be an important determinant factor of landscape change [24]. Conducting research in this area is greatly facilitated by a DTM. However, these data are much more widely applicable in the context of landscape studies. It can be used for the following purposes:

- $\quad$ Landscape valorization [22];

- Classification of landscape based on a viewshed [23];

- Soil-landscape correlations studies in a hilly area [25];

- The assessment of transformations and perspectives of landscape development [26,27];

- Determining the influence of technical infrastructure on landscape value [28];

- Planning and decision-making involving spatial objects, e.g., the placement of economic infrastructure objects [28];

- Creating new trails, as well as modifying and optimizing existing ones [27];

- Valorizing and inventorying as well as taking care of cultural, natural, architectural objects, etc., affecting the landscape value of the region [29];

- Analyzing trends and forecasting threats to existing natural landscape resources [26];

- Promotion and internet advertising using the resources collected in the databases, especially the dissemination of knowledge in the field of landscape protection [28];

- The visualization of landscape projects using all kinds of numerical thematic maps and other cartographic materials, e.g., orthophotomaps [22,30].

The aspects mentioned above are only some examples of how DTM data can be applied in landscape management. There are a significant number of algorithms in software capable of performing DTM data analysis that can examine elevation data. Specialized fields, such as hydrology and forestry, use analysis methods that are closely tailored to their requirements. Additionally, in the field of geomorphology, there are a very significant number of algorithms based on DTM data that are used to characterize the morphology of the terrain. The considerable availability of DTM data processing tools used in specialized fields creates a favorable field for using them in new contexts, linking them to one another, and reinterpreting the results. This is particularly true for landscape studies, which should combine aspects of the specialized fields. 
Considering the developing possibilities to acquire and analyze DTM data, which are great at describing terrain, it is deemed necessary to exploit its diverse potential in landscape research. In this paper, two different methods are proposed to apply DTM data in this field. One of them is a method of reviewing the landscape character and delimitating landscape units using land cover data and a landform classification based on the topographic position index (TPI) described by Weiss [31]. The TPI aggregates information on the absolute height of the terrain, its slope, and the variation in its relief, thus becoming an important indicator describing the landscape in the natural context, which consequently contributes to the ability to support the processes of aesthetic value assessment and landscape valorization. Previous applications of the index have been limited primarily to geomorphological studies. Within the framework of this study, it was considered that the index, together with land cover information, could be very useful in the field of landscape studies, particularly in describing landscape character, which makes the TPI utilized in a new context. The second method is a self-developed method of landscape assessment regarding the possibility of adopting new elements using scenic absorptivity to identify locations of the maximum allowable development height that would not adversely change the landscape. Important elements influencing the physiognomy of the mountain landscape are the components of geomorphological structures, land cover in the areas of mountains, and the character of foothill towns observed from the trails. The value of scenic absorptivity indicated in the study determines the maximum height of space remaining invisible from the adopted viewpoints. With the appropriate selection of these viewpoints, i.e., such that all landscape observation sites important for the given area are included in its set, it is possible to determine the areas whose transformations would not have a negative impact on the landscape values of the area, together with the indication of the maximum permissible height of objects that are components of these transformations. In the context of built-up areas, and in particular, those indicated for development in spatial planning documents, the proposed indicator allows us to de-limit areas of maximum permissible building height, which would not contribute to the loss of identity and physiognomy of the landscape [32] from any number of viewpoints.

Jelenia Góra city, which is characterized by a significantly different landscape, was chosen as the research area. The aim of the study was to assess the city of Jelenia Góra in terms of landscape characteristics, resistance to landscape transformation, and ability to adopt new elements without losing the physiognomy of the landscape. The research was intended to find answers to the following research questions:

1. What is the character of the landscape of Jelenia Góra city in the context of land cover and landform diversity?

2. How does landform diversity and land cover influence the spatial distribution of landscape units of Jelenia Góra city?

3. What is the capacity and spatial distribution of areas able to accept new elements into the Jelenia Góra city landscape without losing its value?

4. How are the development areas of Jelenia Góra city indicated in the study of conditions and directions of land development distributed in the context of scenic absorptivity, and what landscape effects does this have?

5. What is the impact of land cover features on the ability of Jelenia Góra city to absorb new elements into its landscape without losing its values?

6. How useful are DTM data for solving the abovementioned problems?

The constant development and refinement of new landscape analysis methods based on DTM data is an important element in supporting standard research methods. In an era of ever-increasing accessibility to spatial data, advances in data acquisition techniques, the accuracy of these data, and research capabilities, landscape studies using DTM are able to more accurately describe the state and quality of landscape resources and the relationships among them, which in turn leads to a significant improvement in landscape management processes. 


\section{Materials and Methods}

\subsection{Study Area}

The study area consists of Jelenia Góra city situated in the northern part of Jeleniogórska Valley, on the Bóbr River. The area is located in the south-western part of Poland as well as in the south-western part of Lower Silesian Voivodeship. The location of the study area is shown in Figure 1.

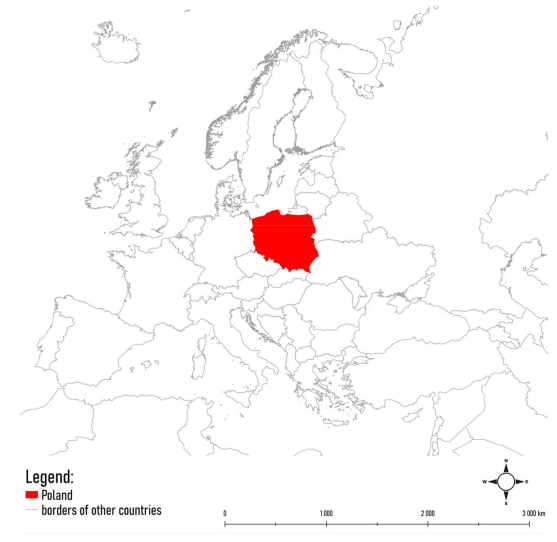

(a)

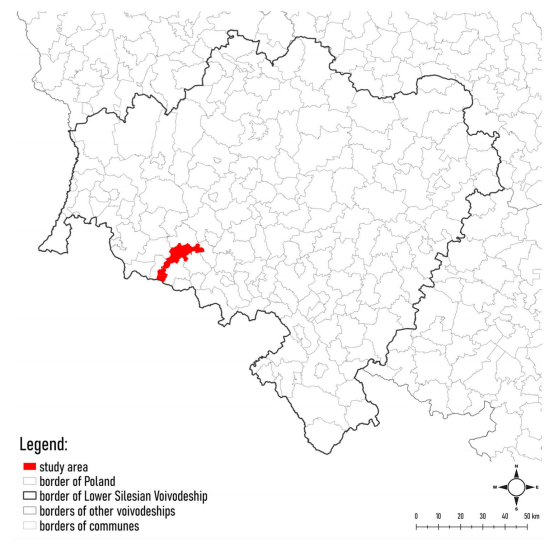

(c)

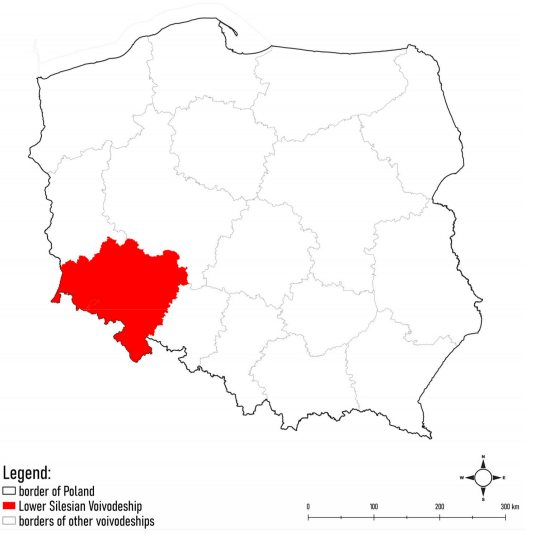

(b)

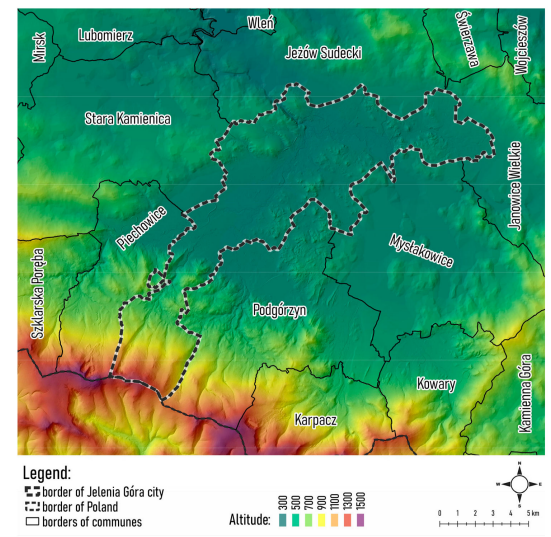

(d)

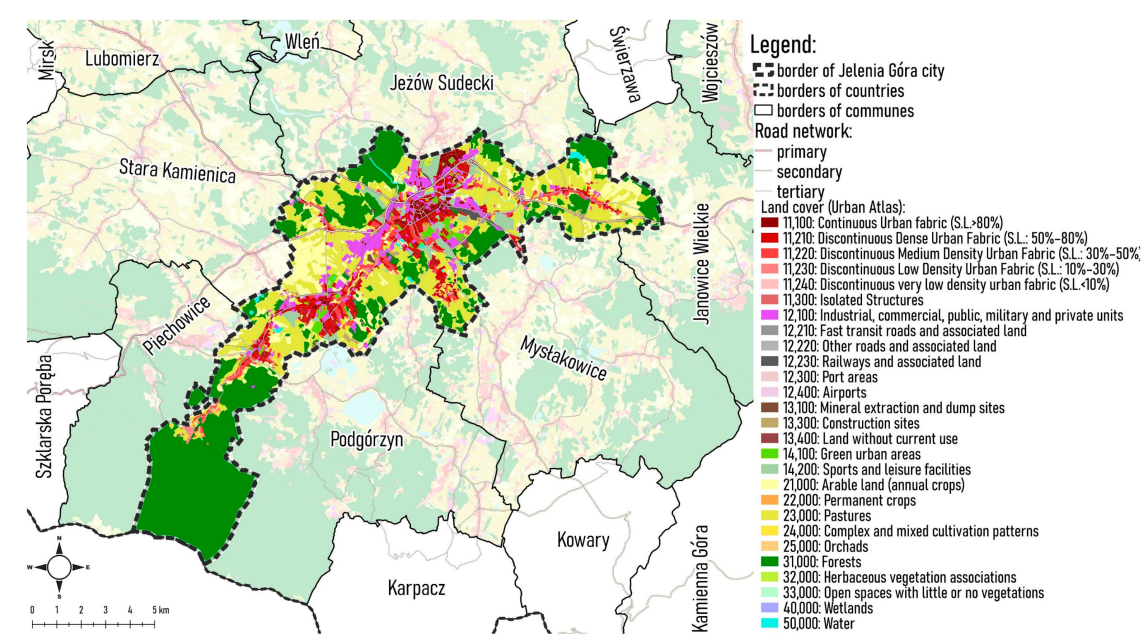

(e)

Figure 1. (a) Location of the study area at the European Union scale; (b) location of the study area at the country scale; (c) location of the study area at the regional scale; (d) digital elevation model of the study area; (e) land cover of the study area (data from Urban Atlas 2018). 
Jelenia Góra, with a total area of $109.2 \mathrm{~km}^{2}$, is among the largest cities in the Lower Silesian Voivodeship. From the south, Jelenia Góra city shares its border with the Czech Republic. The city is surrounded by the Izerskie Mountains and Izerskie Foothills in the west, the Kaczawskie Mountains in the north, the Rudawy Janowickie in the east, and the Karkonosze Mountains in the south, which makes it very attractive for tourism. The high quality of geomorphological forms and natural habitats of the Karkonosze Mountains, which in part are located in the southern zone of the city, as well as other environmentally important areas of Jelenia Góra city, determine the existence of many protected areas in this place, including Karkonoski Park Narodowy (Karkonosze Mountains National Park), Natura 2000 Special Protection Areas (PLB020007), Natura 2000 Special Areas of Conservation (PLH020076, PLH020044, and PLH020006), and "Dolina Bobru" Landscape Park.

As shown in Figure 1e, in general, the land cover of Jelenia Góra city consists of an urbanized core surrounded first by agricultural areas and pastures and then by forest areas. The urban core consists largely of highly urbanized areas and industrial areas, although there are also zones with less intense development.

The altitude within the city ranges from $311 \mathrm{~m}$ to $1416 \mathrm{~m}$ a.s.l. The land in the vicinity of the city is in the form of a basin surrounded by mountains, crossed by the Bóbr River, the terrace of which is the main landscape axis of the area. The study area is characterized by significant diversity in landscape forms. In the general view of the city area, in terms of relief, there are both areas of considerable denivelations and diverse terrain forms, and flat areas with monotonous, relatively undifferentiated relief. The land in the vicinity of Jelenia Góra (a basin surrounded by mountains) and the large height differences mean that this area is characterized by outstanding scenic qualities. From the bottom of the basin, it is possible see the surrounding hills, and from the mountains, it is possible to see the basin. This arrangement creates excellent observational conditions within the context of the local landscape. Jelenia Góra city scenery consists of areas with different characters of both relief and land cover. These include the following: Karkonosze Mountains, which are characterized by the highest dynamics of the natural landscape in terms of land denivelations; Cieplice Depression, which is mostly flat; Izera Foothills, consisting of wide and low hills crossed by the Bóbr River; the central part of Jelenia Góra and Zabobrze, which are characterized by a flat surface and a high level of urbanization; Maciejowa, consisting of a series of hills and small valleys, as well as the valley of the Radomierka River; Łomnickie Hills, characterized by small hills and valleys, as well as built-up areas. The approximate location of the indicated areas is shown in Figure 2.

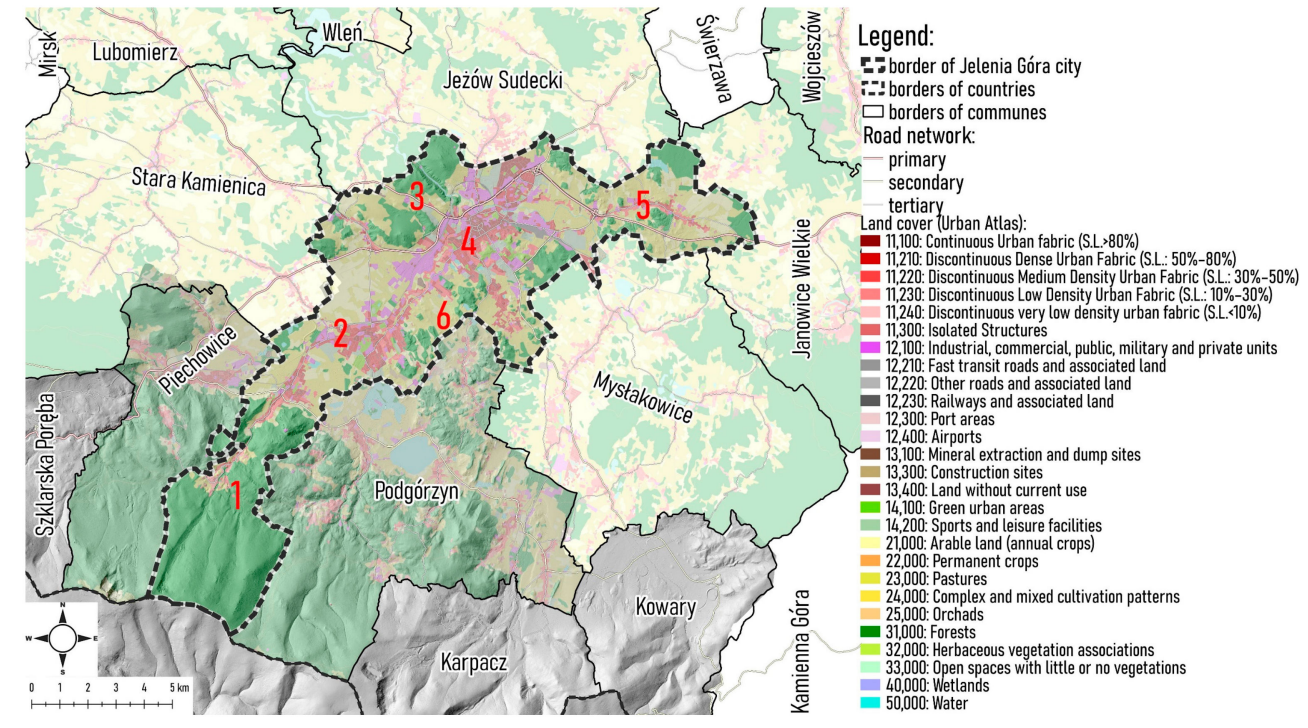

Figure 2. Areas within Jelenia Góra city with different characters of relief and land cover (1-Karkonosze Mountains; 2-Cieplice Depression; 3-Izera Foothills; 4-central part of Jelenia Góra and Zabobrze; 5-Maciejowa; 6-Lomnickie Hills). 
Significant visual diversity of the abovementioned elements within the study area and the local variety of landforms renders the terrain of Jelenia Góra city an interesting object of landscape research. Taking into account the multitude of elements of hills surrounding the city as well as vast plains and slopes, managing the landscape of the study area whilst respecting its physiognomic values becomes an extremely important and difficult task.

In order to achieve better research results, the study area was extended in some stages of analysis by including some point areas of mountain peaks in the Karkonosze Mountains. This expanded the possibilities of assessing the city landscape, a component of which is also undoubtedly the peaks of the Karkonosze Mountains located outside the city borders. These point locations include the following peaks and other important landscape observation points of Jelenia Góra city: Kamenec, Szrenica, Łabski Szczyt, Śnieżne Kotły, Wielki Szyszak, Smogornia, Śnieżka, and Skalny Stół.

\subsection{Method of Jelenia Góra City Landscape Character Diagnosis Using the Topographic Position} Index and Land Cover Map

All the necessary analysis steps were performed in a GIS environment. SAGA GIS, QGIS, GRASS GIS, and ArcGIS software were used for data preparation and analysis, while for final visualization and map export, only QGIS software was used. In this part of research work, data containing a digital elevation model interpolated to $1 \mathrm{~m}$ resolution GRID form was used. It is freely available through the National Geoportal of Poland [32]. The data were acquired using Airborne Laser Scanning technology, during a flight in 2019. A total of 141 DTM datasheets measuring approximately $2.3 \mathrm{~km}$ by $2.3 \mathrm{~km}$ each were acquired for the research. Due to more favorable data storage and computational advantages, the GRID form of the DTM was used during the calculations. To obtain land cover information, the Urban Atlas data was used [33].

In order to conduct a diagnosis of the landscape character of Jelenia Góra city, among the most important steps was to accurately classify the morphological forms using the landform classification method based on the TPI. The method allows us to generate a map representing morphological landforms using only the elevation data stored by DTM. In the literature, the most common methodology of classifying landforms on the basis of TPI is based on the combination of two index maps-with a smaller and a larger surrounding area-determining the local average height, on the basis of which the DTM raster cells are compared [34,35]. By generating TPIs at the appropriate scales, it is possible to correctly adjust to the local conditions of relief. Bearing in mind the above assumptions, it can be noted that an extremely important stage in the classification of morphological forms of terrain on the basis of TPI is the selection of appropriate values of the neighborhood size parameter. In order to accurately match the local terrain conditions of Jelenia Góra city, a number of a sample different scale TPIs were calculated. During the analysis of the results of the sample group of TPIs, it was found that the values of $100 \mathrm{~m}$ as a small scale and $500 \mathrm{~m}$ as a large scale are the most diverse and reflect the differences in the characters of the relief to the greatest extent.

The second extremely important part of the landforms map determination process is the appropriate assumptions made between the TPI rasters at the two scales. Observing the index results at each scale makes it possible to assess which areas of elevation deviation from the mean in the assumed neighborhood illustrated by these results should be considered for landform determination and their values.

By standardizing and combining the TPI rasters at the two chosen scales, 10 types of landforms were distinguished. These forms, in addition to the assumptions in relation to the standardized raster values, are presented in Table 1. In order to better visualize the adopted assumptions, Figure 3 shows a photo taken from the viewing platform "Śnieżne Kotły" with markings of examples of distinguishable landforms. 
Table 1. Landform classification based on standardized and combined TPI rasters at two scales.

\begin{tabular}{|c|c|c|}
\hline Landform Class Number & Landform Classes & Description \\
\hline 0 & deeply incised valleys and ravines & $\begin{array}{l}\text { Small scale: } Z 0 \leq-1 \\
\text { Large scale: } Z 0 \leq-1\end{array}$ \\
\hline 1 & shallow small valleys and slope basins & $\begin{array}{c}\text { Small scale: } \mathrm{Z} 0 \leq-1 \\
\text { Large scale: }-1<\mathrm{Z} 0<1\end{array}$ \\
\hline 2 & valley closures & $\begin{array}{l}\text { Small scale: } Z 0 \leq-1 \\
\text { Large scale: } Z 0 \geq 1\end{array}$ \\
\hline 3 & trough valleys & $\begin{array}{c}\text { Small scale: }-1<\mathrm{Z} 0<1 \\
\text { Large scale: } \mathrm{Z} 0 \leq-1\end{array}$ \\
\hline 4 & flatlands and slopes with a slope of up to $6^{\circ}$ & $\begin{array}{l}\text { Small scale: }-1<\mathrm{Z} 0<1 \\
\text { Large scale: }-1<\mathrm{Z} 0<1\end{array}$ \\
\hline 5 & slopes over $6^{\circ}$ & $\begin{array}{l}\text { Small scale: }-1<\mathrm{Z} 0<1 \\
\text { Large scale: }-1<\mathrm{Z} 0<1\end{array}$ \\
\hline 6 & upper parts of slopes and mesa tops & $\begin{array}{l}\text { Small scale: }-1<\mathrm{Z} 0<1 \\
\text { Large scale: } \mathrm{Z} 0 \geq 1\end{array}$ \\
\hline 7 & secondary local ridges and lateral midslopes & $\begin{array}{c}\text { Small scale: } \mathrm{Z} 0 \geq 1 \\
\text { Large scale: } \mathrm{Z} 0 \leq-1\end{array}$ \\
\hline 8 & lateral ridges and poorly defined culminations & $\begin{array}{c}\text { Small scale: } \mathrm{Z} 0 \geq 1 \\
\text { Large scale: }-1<\mathrm{Z} 0<1\end{array}$ \\
\hline 9 & ridges and culmination tops & $\begin{array}{l}\text { Small scale: } Z 0 \geq 1 \\
\text { Large scale: } Z 0 \geq 1\end{array}$ \\
\hline
\end{tabular}

Source: own elaboration based on Weiss, A. D. Topographic Position and Landforms Analysis [34].

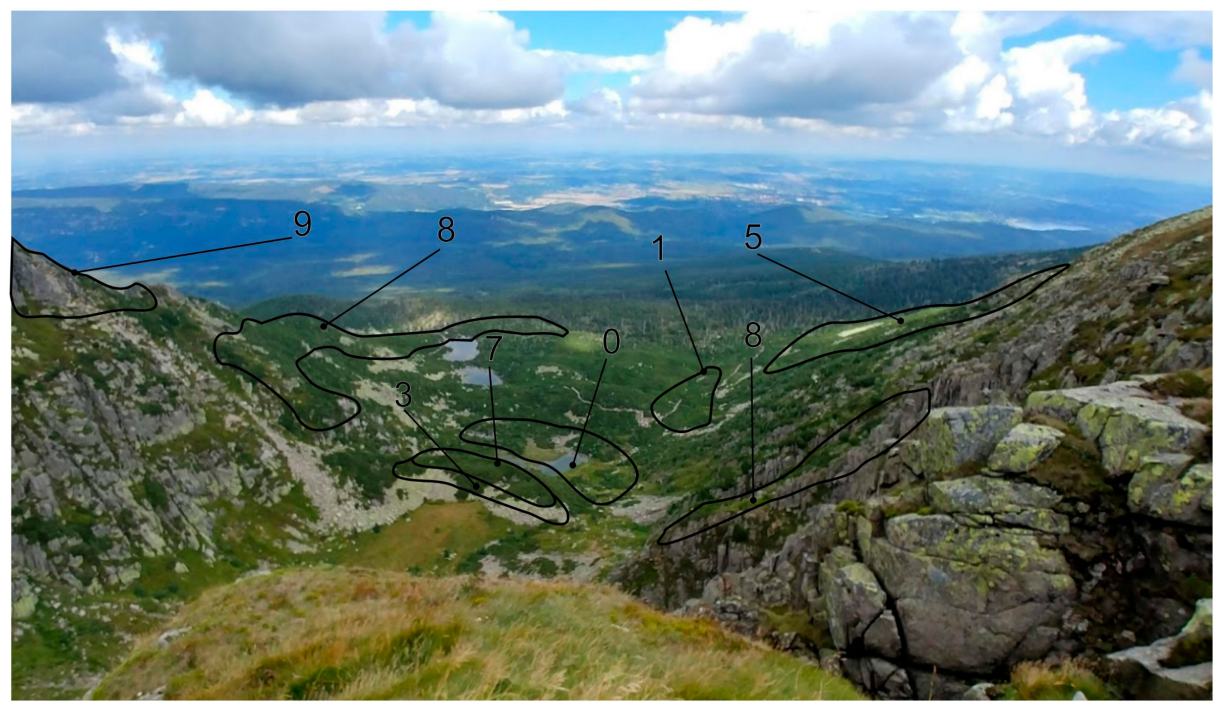

Figure 3. A photo taken from the viewing platform "Śnieżne Kotły" with markings of examples of distinguishable landforms ( 0 - deeply incised valleys and ravines; 1 —shallow small valleys and slope basins; 3 -trough valleys; 5 -slopes over $6^{\circ}$; 7-secondary local ridges and lateral midslopes; 8 -lateral ridges and poorly defined culminations; 9 -ridges and culmination tops).

To obtain the results of the study, particularly in the area of aggregation of results from both issues, the Point Bonitation method was used, which was applied to both land cover data and data containing landforms. The Point Bonitation method is among the frequently used methods in the landscape valuation process. This method provides the fastest and simplest way to determine the location of a selected parameter, despite the inability to assign units to the resulting values [36]. To investigate and synthesize landform and land cover diversity information, the study area was divided into a homogeneous 
network of hexagonal statistical regions of 7.795 ha each, with its centroids spaced $300 \mathrm{~m}$ apart. This network was used to store land cover and landform diversity information in a single, homogeneous spatial division, which allowed us to compare these data. First, an analysis of the number of landforms in each hexagonal region was conducted. In this connection, diversity was categorized as 3 classes for ease of interpretation of the results:

- Class 1, which included statistical regions containing 1 to 3 landforms;

- Class 2, which included statistical regions containing 4 to 6 landforms;

- Class 3, which included statistical regions containing 7 to 9 landforms.

It was assumed that class 1 represents regions that are geomorphologically poorly diversified, class 2 consists of regions that are moderately diverse in terms of the number of landforms, and class 3 represents the high geomorphological diversity of a hexagonal statistical region.

After coding the landform diversity information to the hexagonal statistical regions, an analysis of the dominant proportion of land cover area in each region was conducted. For this purpose, land cover forms were first generalized into three classes:

- $\quad$ Forests, composed of Urban Atlas classes 31,000, 32,000, 30,000, and 13,100;

- Agricultural lands, composed of Urban Atlas classes 21,000, 22,000, 23,000, 24,000, 25,000, and 33,000;

- Urbanized areas, composed of Urban Atlas classes 11,100 11,210, 11,220, 11,230, 11,240, $11,300,12,100,12,210,12,220,12,230,12,300,12,400,13,100,13,300$, and 13,400.

After aggregating the Urban Atlas land cover resources into three polygons relative to the listed classes, an operation was performed to intersect the resource with hexagonal statistical regions. In this way, a resource containing information on the area of each generalized land cover class in each statistical polygon was obtained. In order to qualify each statistical region to a particular generalized land cover class, the rules shown in Table 2 were followed.

Table 2. Rules for classifying hexagonal statistical regions into specific land cover classes.

\begin{tabular}{|c|c|c|c|c|c|c|c|c|}
\hline & & \multicolumn{7}{|c|}{ The Land Cover Class Adopted for the Hexagonal Region } \\
\hline & & Forests & $\begin{array}{l}\text { Agricultural } \\
\text { Lands }\end{array}$ & $\begin{array}{l}\text { Urbanized } \\
\text { Areas }\end{array}$ & $\begin{array}{c}\text { Forests and } \\
\text { Urbanized } \\
\text { Areas }\end{array}$ & $\begin{array}{l}\text { Forests and } \\
\text { Agricultural } \\
\text { Lands }\end{array}$ & $\begin{array}{l}\text { Agr. Lands and } \\
\text { Urbanized } \\
\text { Areas }\end{array}$ & $\begin{array}{l}\text { Mixed } \\
\text { Areas }\end{array}$ \\
\hline 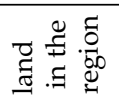 & Forests & $>60 \%$ & - & - & $>25 \%$ & $>25 \%$ & $<25 \%$ & rest \\
\hline 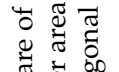 & Agricultural lands & - & $>60 \%$ & - & $<25 \%$ & $>25 \%$ & $>25 \%$ & rest \\
\hline 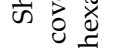 & Urbanized areas & - & - & $>60 \%$ & $>25 \%$ & $<25 \%$ & $>25 \%$ & rest \\
\hline
\end{tabular}

Once each hexagonal statistical region was classified into its unique generalized land cover class, data containing this information were combined with the landform diversity. In order to characterize the landscape of Jelenia Góra city, each hexagonal statistical region was classified in terms of land cover class and level of landform diversity into a specific landscape category.

In order to delineate landscape units of Jelenia Góra city, information on land cover and the spatial distribution of individual landforms was overlaid on one map. This operation allowed us to observe physiognomically coherent areas with clearly outlined borders. Landscape units were delineated on the basis of both the superimposed landforms and land cover data and the hexagonal map of landscape characteristics discussed above.

The results of landscape character analysis should only be interpreted as visual factors that shape the landscape of the area. In addition to geomorphological factors and land cover information, other important elements, such as socioeconomic aspects, soil properties, vegetation regeneration potential, and vegetation diversity, were not included in this study. 
To better understand the methodological steps carried out to identify the landscape character of Jelenia Góra city using DTM data, a schematic diagram describing them is presented in Figure 4.

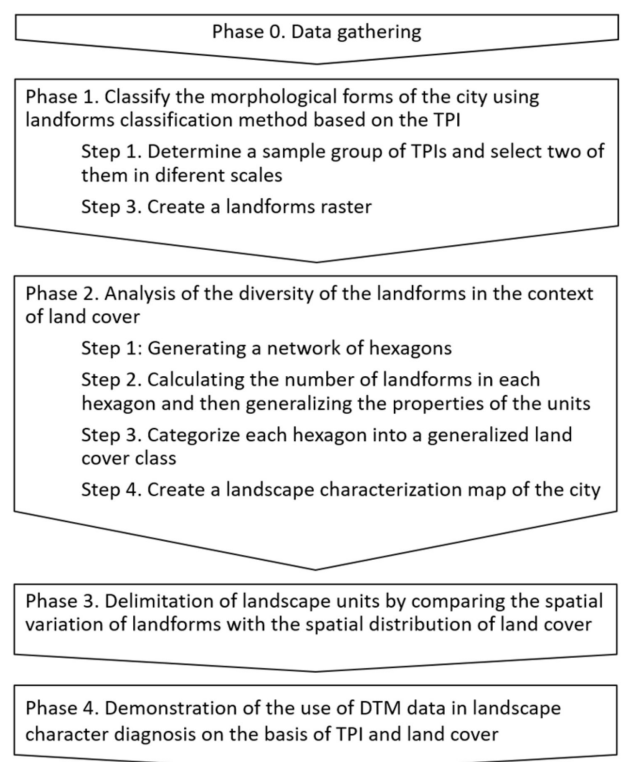

Figure 4. A diagram describing methodological steps carried out to identify the landscape character of Jelenia Góra city using DTM data.

2.3. Method of Landscape Assessment of Jelenia Góra City in Terms of the Possibility of Adopting New Elements, Using the Scenic Absorptivity

All the necessary analysis steps were performed in a QGIS environment. In this part of research work, data containing a digital situation model and a digital elevation model interpolated to a $1 \mathrm{~m}$ resolution GRID form were used. A total of 282 datasheets (141 of DEM and 141 of DSM) measuring approximately $2.3 \mathrm{~km}$ by $2.3 \mathrm{~km}$ each were acquired for the research. During the GIS analyses, both GRID and TIN structural forms of the digital terrain model were used. Due to more favorable data storage and computational advantages, the GRID form of the DTM was used for the calculations. The TIN form, on the other hand, served as a component of some of the analyses for which the GRID form would not serve an appropriate role.

The first step of the analysis was to determine the visibility field from selected vantage points. Due to significant demand of the algorithms calculating the visibility field on the computational power of the computer, only the highest and most exposed mountain peaks and vantage points were selected for the set of the most important Karkonosze landscape observation points. The following were included: Śnieżka, Szrenica, Łabski Szczyt, Śnieżne Kotły, Wielki Szyszak, Smogornia, Kamenec, and Skalny Stół. The scale of scenic absorptivity was calculated on the basis of DSM, which stores information on both the height of relief and the elements of its coverage, and DEM, which indicates only the height of relief. Thanks to this, the determination of the visibility field from the adopted points took the following into account separately:

1. The existing buildings and forest areas, which are often an important element limiting the visibility field;

2. The relief itself, which is a permanent component of the landscape, as opposed to land cover elements that may be subject to transformation.

The next step was to build a TIN model from points representing the boundary of areas invisible from the adopted viewpoints and convert it to the raster form. Thanks to that, the absolute height of the area identical to the upper limit of the invisible space from the given viewpoints was indicated. This operation was performed twice-on the basis of DEM and DSM data. 
The subsequent step was to reclassify the DTM raster and the upper boundary of the invisible space raster created from the TIN model in order to preserve its absolute heights in the invisible areas and to assign a value of 0 to the cells identical to the visible areas. The final step was to subtract the value of the reclassified altitude raster from the reclassified TIN model raster. The subtract operation resulted in the difference of the absolute height of the upper limit of the invisible space and the ground level. The obtained values determine the areas defining the maximum height relative to the ground level of the invisible space from the assumed viewpoints. To better understand the principles of scenic absorptivity, it is shown in schematic cross section in Figure 5.

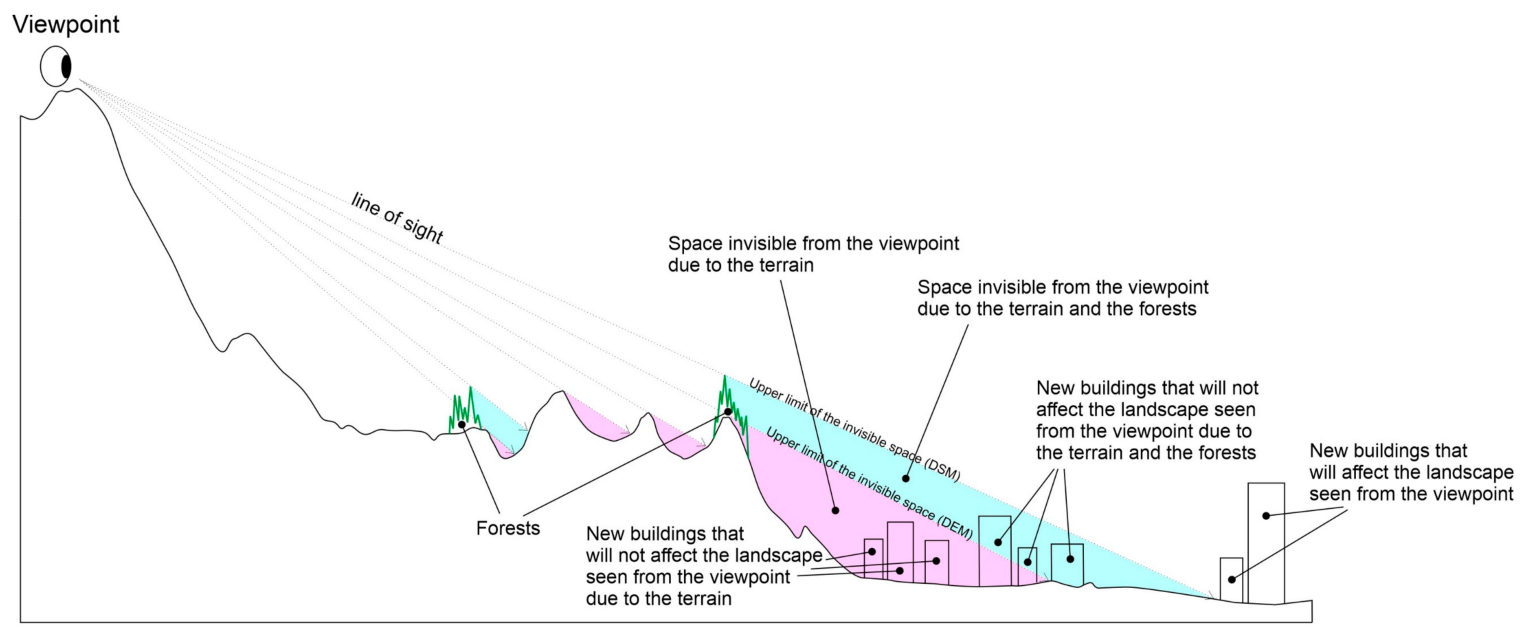

Figure 5. Schematic terrain cross-section illustrating the principles of scenic absorptivity.

The final phase in the assessment of the possibility of adopting new elements in the landscape of Jelenia Góra city landscape was to overlay the scenic absorptivity results onto the map of the development directions contained in the study of conditions and directions of land development of Jelenia Góra city. Thanks to this operation, an assessment was made of the influence of the areas planned for development in the document on the change in the landscape of Jelenia Góra city. For this purpose, areas planned for building development were reviewed and, on the basis of the scenic absorptivity scale, those that would remain invisible from the adopted viewpoints were identified. It was assumed that areas with a significant scale of scenic absorptivity would not affect the local landscape transformation much, while areas with no scenic absorptivity, after development, would have a greater impact on changing the landscape of the city. This analysis allowed us to assess which solutions contained in the spatial planning document would contribute most to landscape transformation, and in which places it is possible to introduce development that would not contribute to this process.

To better understand the methodological steps carried out to assess Jelenia Góra city in terms of the possibility of adopting new elements, using the scenic absorptivity based on DTM data, a schematic diagram describing them is presented in Figure 6.

Among the terrain features relevant to view analyses, the most objective and enduring is the relief of the terrain (for example, compared to seasonality of vegetation or variability of atmospheric factors). Therefore, the results of the scenic absorptivity analysis conducted using the DEM should be treated as "hard", indicating areas that, regardless of landscape changes, such as deforestation or building demolitions, would not affect the landscape observed from the adopted, essential viewpoints. However, in order to fully represent the actual scenic absorptivity value closest to reality, the model most similar to the real situation should be taken into account. On the other hand, if it is necessary to be certain about the possibility of introducing new elements into the landscape that would not affect it, e.g., in the case of tourist investments, such as a large hotel, the results of the scenic absorptivity analysis performed on the DEM should be taken into consideration first. In the era of 
the expansive introduction of tourist objects that can often degrade the landscape, scenic absorptivity analysis should be among the basic preventive factors in landscape protection.

\begin{tabular}{|c|}
\hline Phase 0. Data gathering \\
\hline $\begin{array}{l}\text { Phase } 1 \text {. Conduct the scenic absorptivity of the city on both DEM } \\
\text { and DSM basis }\end{array}$ \\
\hline $\begin{array}{l}\text { Step } 1 . \text { Viewshed analysis based on selected observation } \\
\text { points on both DEM and DSM basis }\end{array}$ \\
\hline $\begin{array}{l}\text { Step 2. Calculate the difference between the absolute } \\
\text { height of the terrain in places not visible from the adopted } \\
\text { viewpoints and the absolute height of the space remaining } \\
\text { invisible from these points on both DEM and DSM basis }\end{array}$ \\
\hline $\begin{array}{l}\text { Phase } 2 \text {. Analyze the impact of land cover elements on scenic } \\
\text { absorptivity }\end{array}$ \\
\hline $\begin{array}{l}\text { Step 1. Compare the volume of invisible space form DEM } \\
\text { and DSM }\end{array}$ \\
\hline $\begin{array}{l}\text { Phase 3: Analyze the study of conditions and directions of land } \\
\text { development of Jelenia Góra city in order to indicate objects } \\
\text { correctly situated and incorrect ones in the context of its } \\
\text { influence on the local landscape }\end{array}$ \\
\hline $\begin{array}{l}\text { Phase } 4 \text {. Demonstration of the use of DTM data in landscape } \\
\text { assessment in terms of the possibility of adopting new elements, } \\
\text { on the basis of the proprietary scenic absorptivity method }\end{array}$ \\
\hline
\end{tabular}

Figure 6. A diagram describing methodological steps carried out to assess Jelenia Góra city in terms of the possibility of adopting new elements, using the scenic absorptivity based on DTM data.

\section{Results}

\subsection{Jelenia Góra City Landscape Character Diagnosis}

Among the important factors defining the character of a mountain landscape is the diversity of landforms. Digital DTM data analysis tools enable us to quantify this. Among many methods of analyzing digital elevation data, the topographic position index (TPI) provides one of the most effective and simplest methods of classifying terrain morphological forms $[34,35,37]$. To create a map of landforms in this study, TPI was used at the following two scales:

- The first was $100 \mathrm{~m}$, based on which it is possible to indicate-among other shallow small valleys and slope basins, flatlands and slopes with a slope of up to $6^{\circ}$-slopes over $6^{\circ}$, secondary local ridges, and lateral midslopes, as shown in Figure 7a;

- The second was $500 \mathrm{~m}$, based on which it is possible to indicate-among other trough valleys, flatlands, and slopes with a slope of up to $6^{\circ}$-slopes over $6^{\circ}$, upper parts of slopes, and mesa tops, as shown in Figure $7 \mathrm{~b}$.

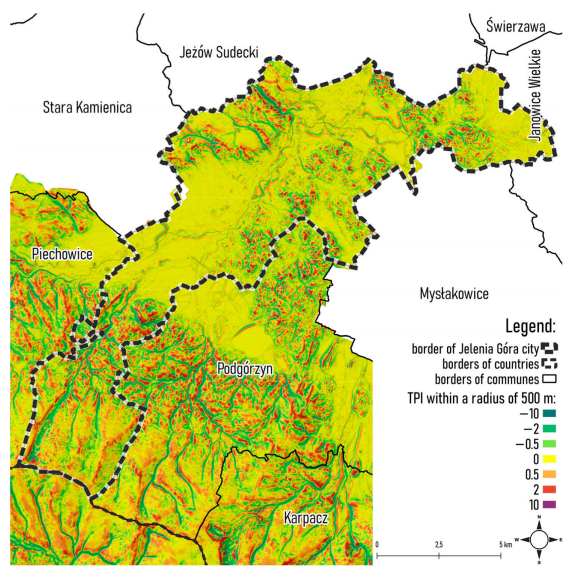

(a)

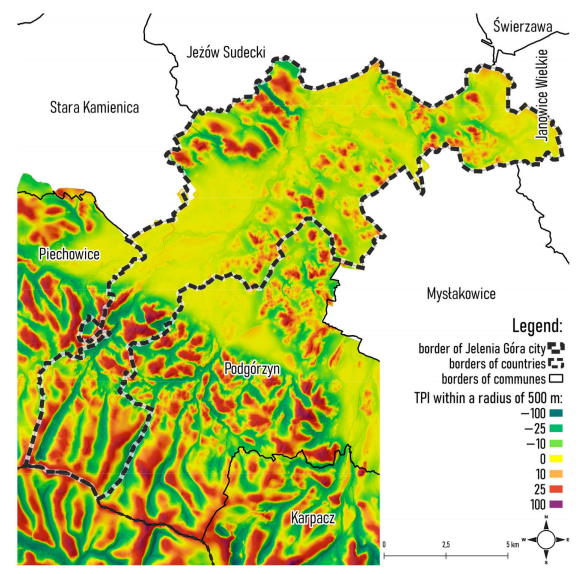

(b)

Figure 7. (a) Topographic position index based on $100 \mathrm{~m}$ radius (scale from $-10 \mathrm{~m}$ to $10 \mathrm{~m}$ ); (b) topographic position index based on $500 \mathrm{~m}$ radius (scale from $-100 \mathrm{~m}$ to $100 \mathrm{~m}$ ). 
Standardizing and combining TPI rasters at two scales allowed us to classify landforms reflecting either large-scale geomorphic elements resulting from large-scale TPI or fine-scale elements resulting from small-scale TPI. Selecting the two index scales at the $100 \mathrm{~m}$ and $500 \mathrm{~m}$ levels allowed us to extract landform information from the DTM data adapted to the scale of the study area. The results of the analysis allowed us to show the characteristics of the Jeleniogórska Valley completely flat depressions, flat-bottomed river valleys, and island hills with rock formations, as well as those typical for the Karkonosze Foothills and the Karkonosze Mid-Mountain Carcass highlands separated by small plains and deep valleys. The result of the landform analysis, in the shape of a map of geomorphological forms, is shown in Figure 8. Figure 9 shows a northeast view of a portion of the 3D model, representing the Karkonosze Mountains, with the landforms layer overlaid.

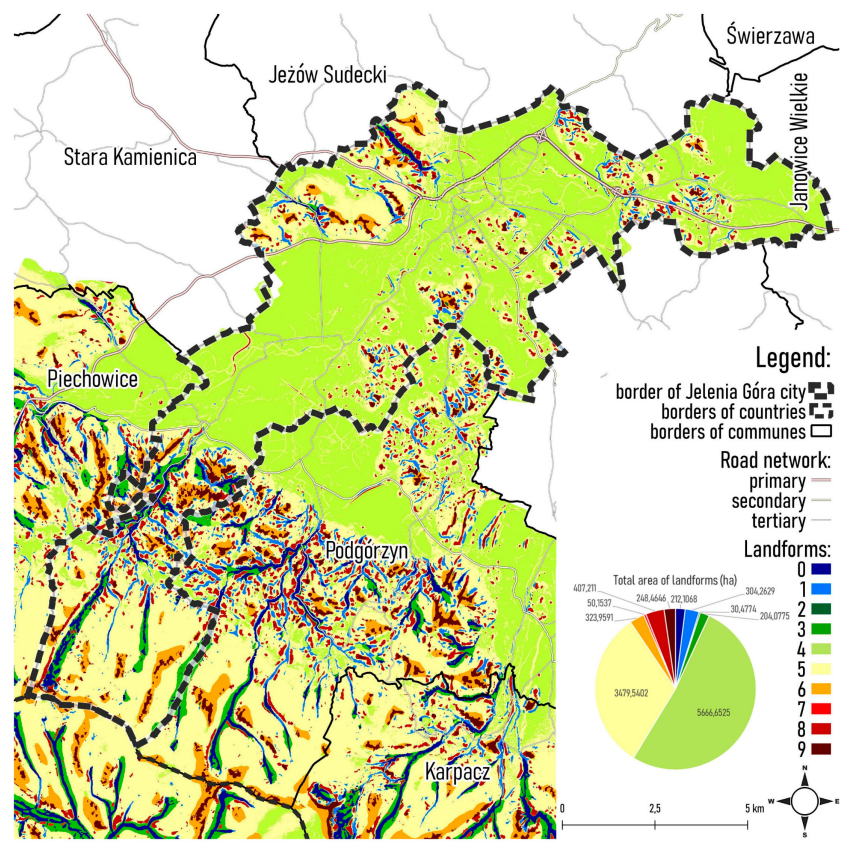

Figure 8. Landform classification based on standardized TPI rasters at the two scales (0-deeply incised valleys and ravines; 1 -shallow small valleys and slope basins; 2 -valley closures; 3 -trough valleys; 4 -flatlands and slopes with a slope of up to $6^{\circ} ; 5$-slopes over $6^{\circ} ; 6$-upper parts of slopes and mesa tops; 7-secondary local ridges and lateral midslopes; 8-lateral ridges and poorly defined culminations; 9-ridges and culmination tops).

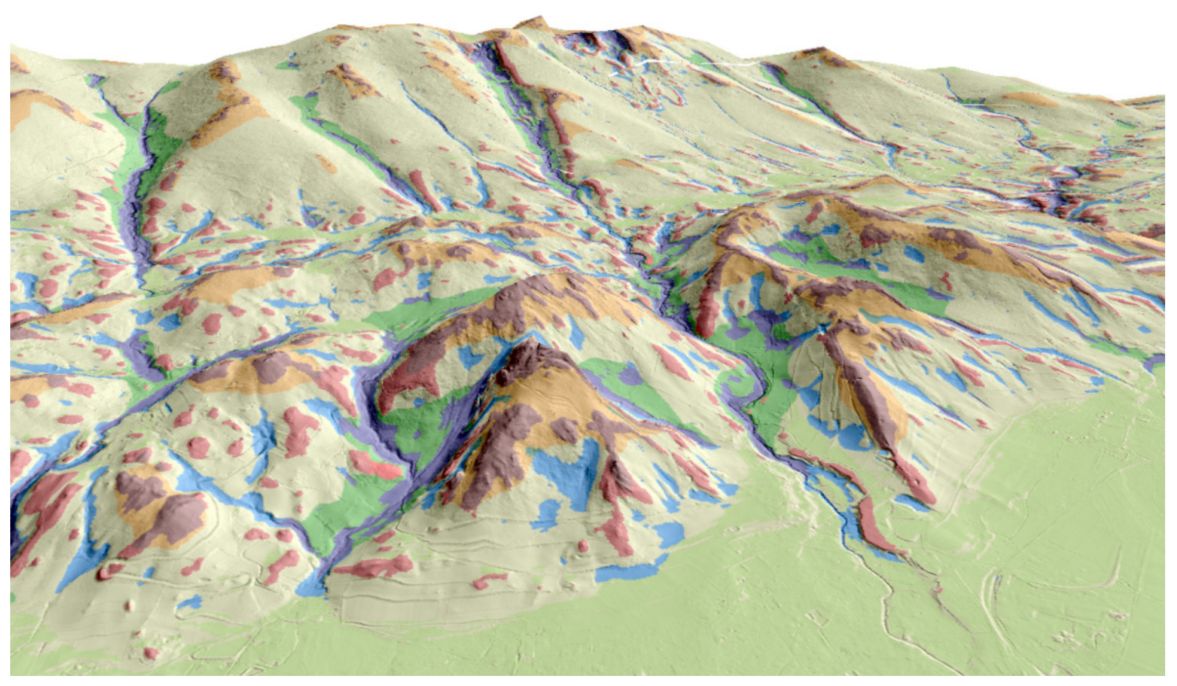

Figure 9. View of the Karkonosze Mountains landforms 3D model from the north-east. 
Based on the TPI, 10 landforms were distinguished in the analysis area. In terms of the spatial distribution of the landforms, the city area can be divided into two main zones: the north, which is a part of the Jeleniogórska Valley Depression, and the south, which is a part of Karkonosze Mountains. In terms of the size of fields of individual geomorphological forms, the majority of them are flatlands and slopes with a slope of up to $6^{\circ}$. These areas are located mostly in the central part of the study area, especially in the vicinity of Cieplice. Slopes over $6^{\circ}$ also occupy a significant part of the city. These landforms, in turn, are located in the southern part of the study area, which is included in the Karkonosze Foothills and the Karkonosze Mid-Mountain Carcass, as well as in the north-western part of the city, near the deep valley of the Bóbr River. In general, it can be considered that due to its dominance in space, flatlands and slopes over $6^{\circ}$ are a background for other landforms. The Bóbr River Valley itself in the western part and its surroundings comprise the most geomorphologically distinctive part of the northern zone of the city. Additionally, in the eastern part of the northern zone, there are some isolated and island-like hills, which makes it distinct from the surrounding landscape. The southern part is characterized by a much more complex geomorphological form. The northern part of the southern zone of the study area, Karkonosze Foothills, consists of a hilly area composed of many separate hills and smaller and larger valleys, which makes the structure of this part easily distinguishable in the context of the city. Further south, the number of small hills and the frequency of valleys decreases, giving way to areas of slopes over $6^{\circ}$ and upper parts of slopes and mesa tops.

An important factor determining the quality of the landscape and characterizing it, especially in the context of the mountain landscape, in addition to the occurrence of different morphological forms, is the level of its diversity. In this study, maps indicating the level of landform diversity were developed and divided into hexagonal statistical regions. The amount of landform diversity was marked as the number of types of landforms in one statistical region, as shown in Figure 10a. For subsequent analytical processes, the detailed diversity of landforms was generalized into three classes, as shown in Figure 10b. This result provided a starting point for further analysis in subsequent research processes.

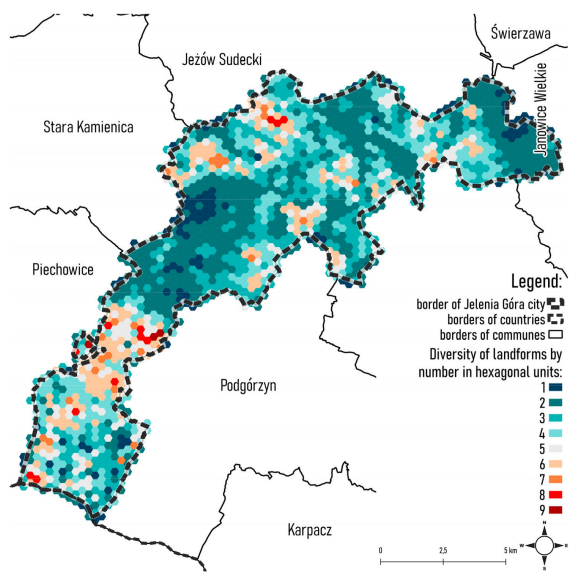

(a)

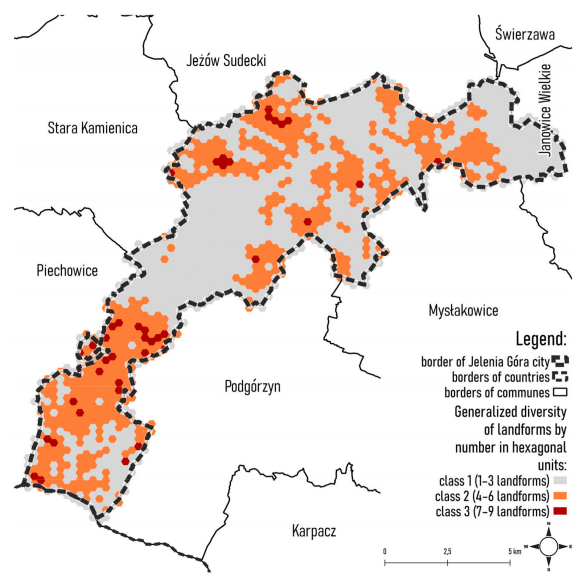

(b)

Figure 10. (a) Diversity of landforms understood as the number of types of landforms in the adopted hexagonal statistical region; (b) diversity of landforms generalized into three classes in the adopted hexagonal statistical region.

The analysis of landform diversity allowed us not only to assess the degree of diversity of landforms, but most importantly to prove the potential landscape value and may be among the factors able to describe the character of the landscape. The results of the diversity of landform analysis indicate that the southern part of the study area (Karkonosze Mountains) is potentially characterized by the highest landscape values. Additionally, the hills and small elevations located peripherally to the city center are potential areas of high landscape value, especially the area of the Bóbr River Valley in the western part of the city. 
Landform diversity only describes the landscape in terms of relief. In order to complete the diagnosis of landscape characteristics of Jelenia Góra city, the results of this part of research were synthesized with information on land cover. The land cover map from the Urban Atlas, in order to make the analysis easier to perceive without overcomplicating the results, was simplified into three main classes, as shown in Figure 11a. Figure 11b, on the other hand, shows the dominant share of the area of the generalized land cover class in the hexagonal statistical regions, which made it possible to compare this information with the magnitude of landform diversity.

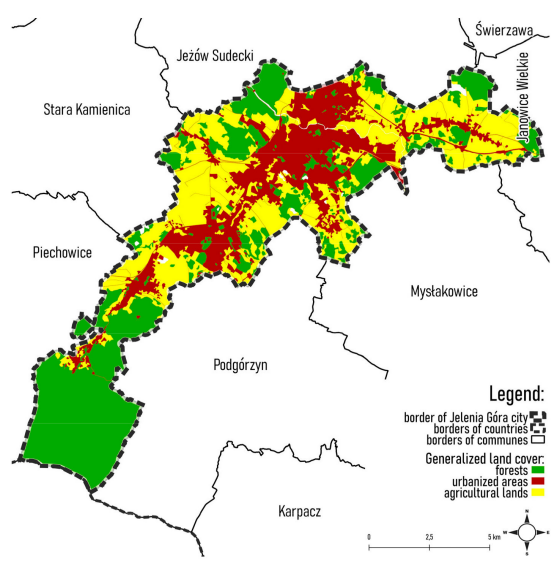

(a)

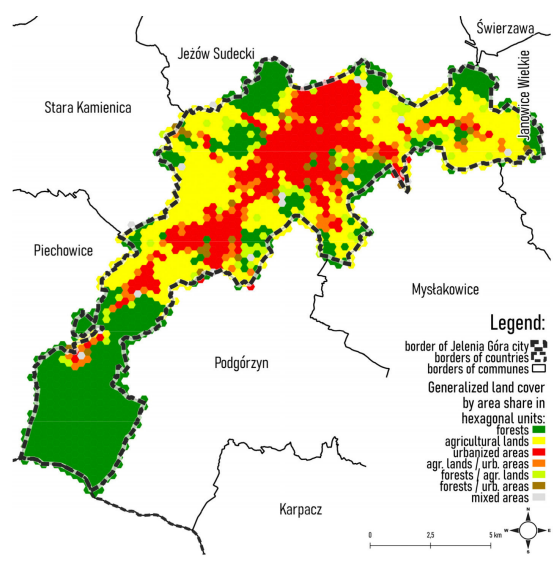

(b)

Figure 11. (a) Land cover generalized into three classes; (b) the dominant share of an area of one of the three generalized land cover classes or the mixed share of land cover classes in the adopted hexagonal statistical region.

The analysis of land cover and landform diversity by homogeneous statistical regions resulted in a resource containing information on landform diversity within each land cover class. The data provide information on the level of land variability and the spatial distribution of land cover, and combine this information indicating the level of variation in geomorphological forms within each of the adopted land cover classes. These data were used to create generalized characteristics of the landscape of Jelenia Góra city in terms of topography and land cover, as shown in Figure 12.

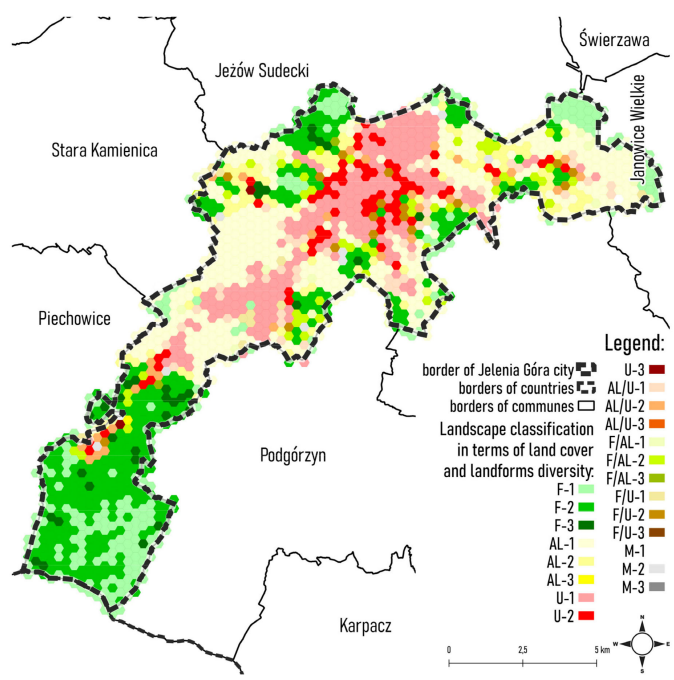

Figure 12. Jelenia Góra city landscape characteristics map: diversity of landforms by a hexagonal statistical region according to the largest share of an area of one of the three generalized land cover classes or a mixed share of land cover classes (F-forests; AL-agricultural lands; U—urbanized areas; numbers 1 to 3 - the diversity of landform class number). 
The result of the characteristic analysis of the landscape of Jelenia Góra indicates various classes of land cover in terms of the number of geomorphological forms. As shown in Figure 13b, the urban landscape of Jelenia Góra city is characterized by the smallest share of area among all classes of land cover. The main core of the urbanized landscape is Jelenia Gora city center and Cieplice. These areas are additionally extended by peripheral urbanized areas in the form of Maciejowa located in the north, and Sobieszów located in the south. As shown in Figure 13a, urbanized areas are mostly characterized by low landform diversity, although there is also a group of areas with medium diversity. These areas can be found on the one hand in the vicinity of Sobieszów, but mainly on the outskirts of the town center. As shown in Figure 13b, the forests landscape of Jelenia Góra city is characterized by the largest share of area among all classes of land cover. The largest concentration of forested landscape is in the southern part of the study area, although it is also present in the areas peripheral to the urban core, especially on the side of the village of Siedlęcin. As shown in Figure 13a, forested areas are the most geomorphologically diverse of all land cover classes. Among the forested areas, medium landform diversity dominates, although it is also the only group of land cover classes that has a visible proportion of areas with high landform diversity. As shown in Figure 13b, the agricultural landscape has an average proportion of area relative to other land cover classes. In terms of spatial distribution, it complements urbanized and forested areas-it somehow spans over the other classes. As shown in Figure 13a, agricultural areas are characterized by low landform diversity. Among them, areas with little diversity are the most numerous, although areas with medium variation of landforms also appear in some places, especially around the hills surrounding the city center. Agricultural areas with low landform diversity are the largest group in the area of Jelenia Góra city. There are also mixed areas in the landscape of Jelenia Góra city. They are usually located at the junction of classes of which it represents a hybrid. However, its area is marginal in the total study area. Both among the areas covered by forests or agricultural lands and among urbanized areas, there are places with and without significant diversity between landforms.

As shown in Figure 13c, except for mixed classes, which represent a marginal share of the area, Jelenia Góra city's most landform-diverse land cover class is forests. On average, there are approximately four types of landforms in one hexagonal region. Next in terms of diversity is the class of urbanized areas, where on average there are 2.8 types of landforms per statistical region. The least geomorphologically differentiated class is agricultural areas, where there are, on average, 2.5 types of landforms per hexagonal region.

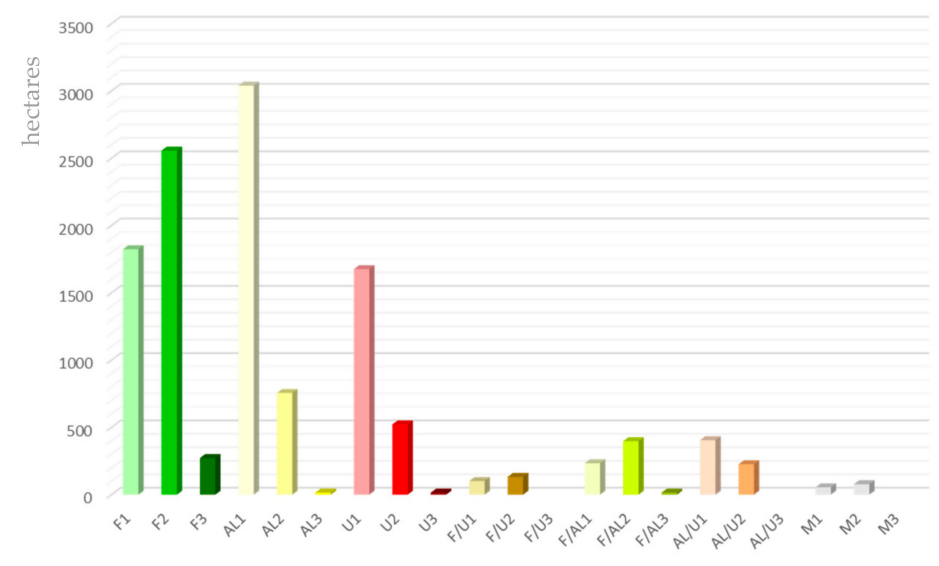

(a)

Figure 13. Cont. 


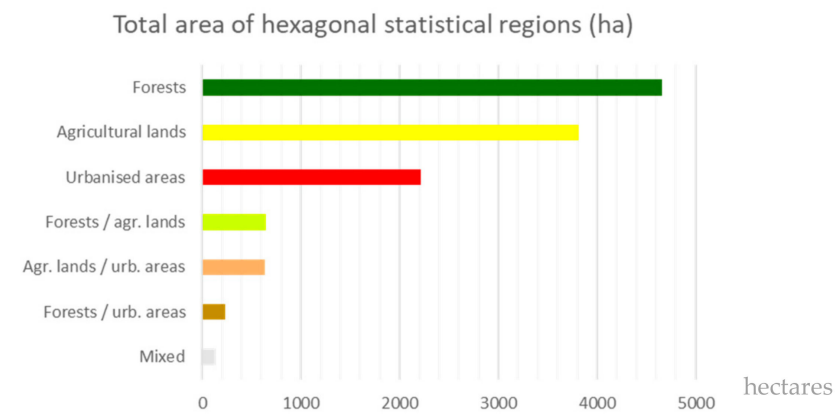

(b)

Average landforms number in hexagonal statistical region

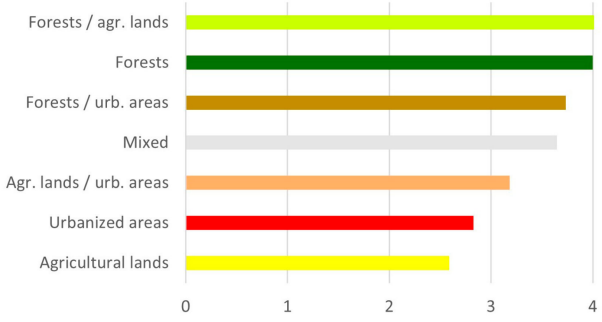

(c)

Figure 13. (a) Magnitude of total area (ha) of hexagonal statistical regions by land cover generalized classes and diversity of landforms classes (F-forests; AL-agricultural lands; U—urbanized areas; numbers 1 to 3 -the diversity of landforms class number); (b) total area of hexagonal statistical regions per land cover generalized class (ha); (c) average number of types of landforms in a hexagonal statistical region by generalized land cover class.

On the basis of the analyzed characteristic features of the Jelenia Góra city landscape and supporting the spatial distribution of detailed information on land cover and the distribution of landforms, the delimitation of landscape units of Jelenia Góra city was carried out. The designated landscape units constitute geomorphologically and land coverdistinct areas, each of which is characterized by a different landscape character. The results are shown in Figure 14.

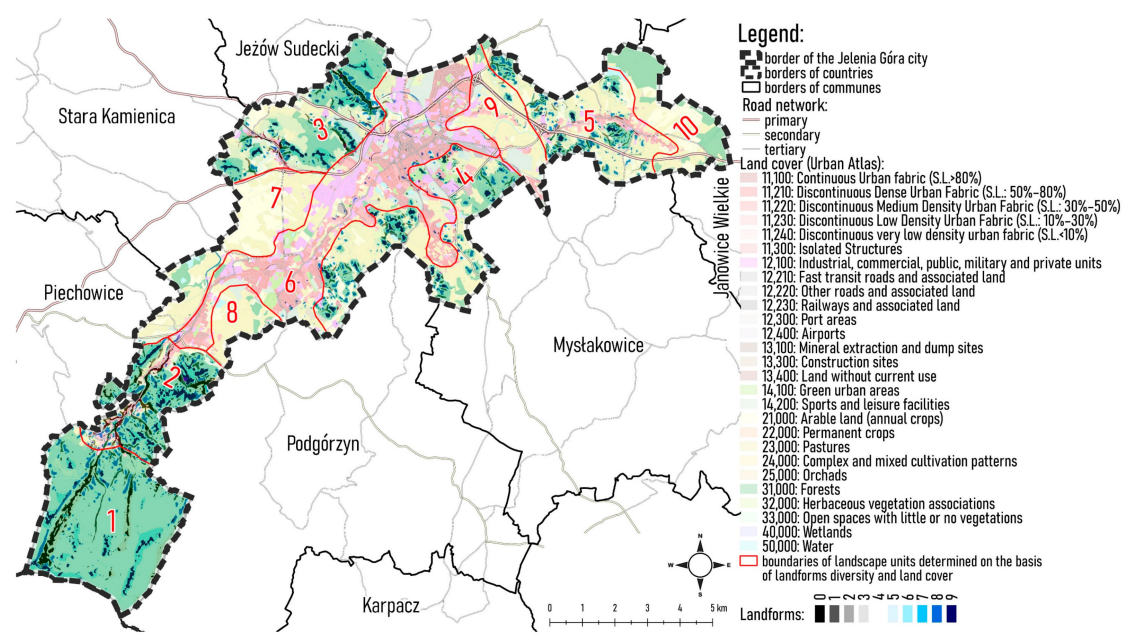

Figure 14. Landscape units determined from a synthesis of land cover and landforms maps (1-“Karkonosze Mountains"; 2-“Sobieszów"; 3-“Izera Foothills"; 4-“Łomnickie hills"; 5-“Maciejowa west"; 6- "Urban core of Jelenia Góra city"; 7-“Cieplice depression west"; 8-“Cieplice depression east"; 9-“Strupice"; 10—“Maciejowa east"). 


\subsection{Assessment of the Landscape of Jelenia Góra City in Terms of the Possibility of Adopting} New Elements

Below are a number of outcome maps that show the results of each step in the scenic absorptivity determination process. Figure 15a shows the visibility field from the adopted cityscape observation points. This is the initial step of determining scenic absorptivity. The next step of vectorizing the invisibility field and converting the polygon vertices into points is shown in Figure 15b.

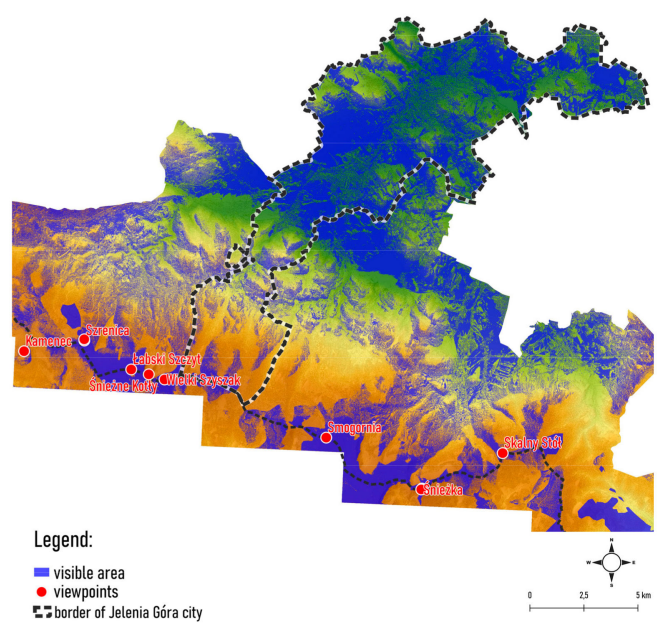

(a)

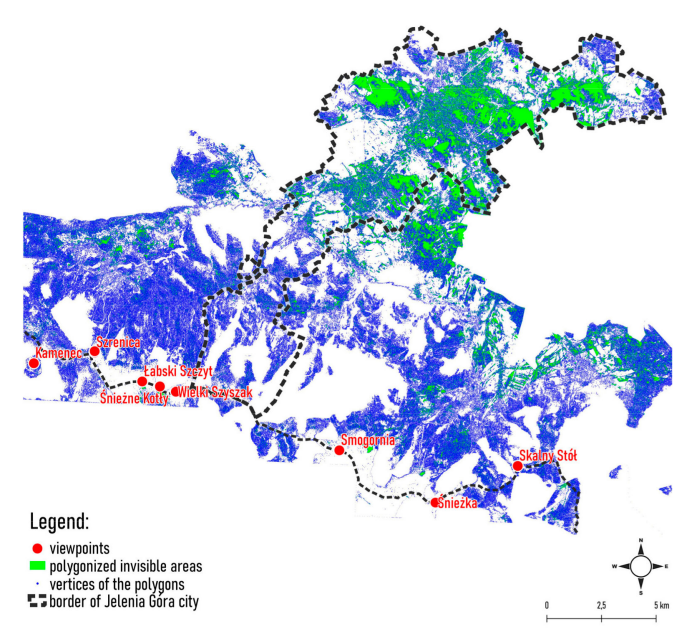

(b)

Figure 15. (a) Area visible from viewpoints (invisible areas are transparent); (b) result of polygonization of the visibility raster and extraction of vertices from the polygons.

Figure 16a shows the absolute height of the upper boundary of the invisible space from the adopted cityscape observation points. This resource, together with the absolute height of the terrain in the non-visible areas shown in Figure 16b, provides the necessary data for the next steps of the analysis.

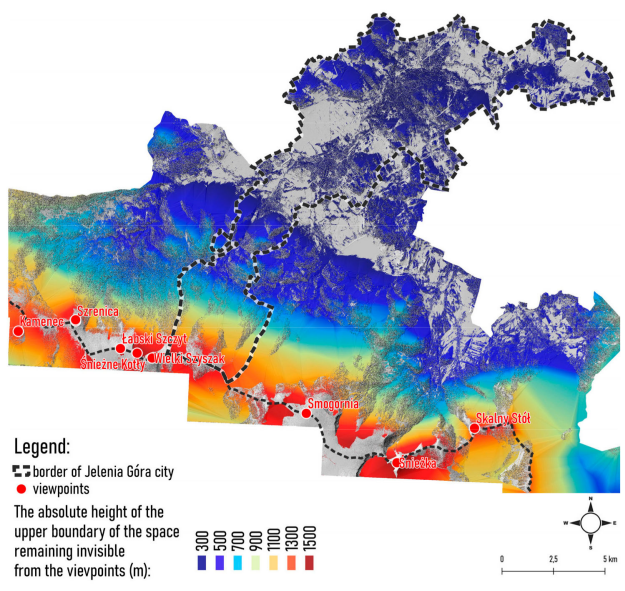

(a)

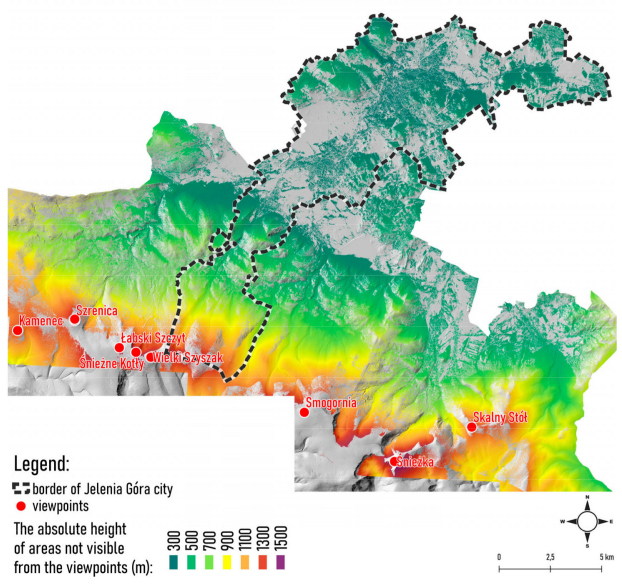

(b)

Figure 16. (a) The absolute height of the upper limit of the invisible space from the viewpoints in invisible areas; (b) the absolute height of areas not visible from the viewpoints.

By subtracting the absolute terrain height rasters from the upper boundary of the invisible space from the assumed points, the scenic absorptivity was obtained. The result of the analysis is shown in Figure 17a. Figure 17b shows a close-up on the central urbanized part of the city. 


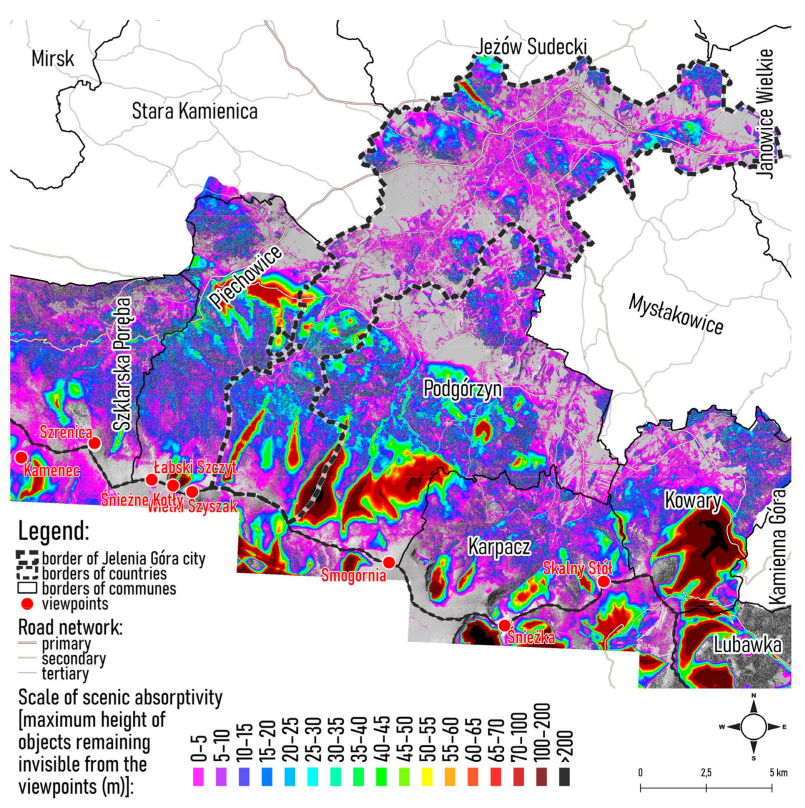

(a)

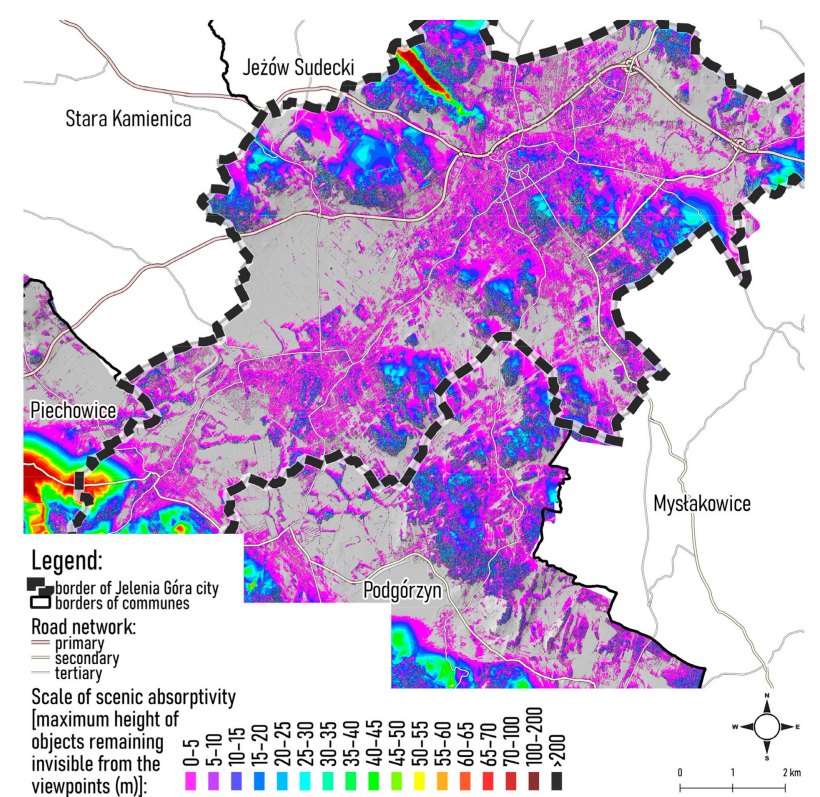

(b)

Figure 17. (a) Scenic absorptivity of Jelenia Góra city based on digital situation model and calculated using the most important mountain viewpoints of the Karkonosze Mountains; (b) scenic absorptivity of Jelenia Góra city based on digital situation model and calculated using the most important mountain viewpoints of the Karkonosze Mountains-close-up on the city.

The greatest scenic absorptivity in the study area was found in the areas of valleys and spaces behind the hills located in the Karkonosze Foothills. The significant size of the area invisible from the adopted viewpoints is caused by the considerable diversity among landforms here. In the valley located on the border of the city in the south-eastern part, the scale of scenic absorptivity is so large that it would allow objects up to $200 \mathrm{~m}$ high to be placed here, which would remain invisible from the adopted viewpoints. In the other Karkonosze Foothills valleys, the scale of the scenic absorptivity is not as large, but still remains extremely significant, in the range between $70 \mathrm{~m}$ and $100 \mathrm{~m}$. In the area located closer to the city center, the western part of the Bóbr River Valley is characterized by the greatest scenic absorptivity. This is due to the trough character of the valley that cuts across the hills in this place. Most of the scenic absorptivity in significantly urbanized areas comprises small spaces up to $5 \mathrm{~m}$ and sometimes $10 \mathrm{~m}$ in scale. There are, however, zones with larger surface areas and a scale of scenic absorptivity up to $50 \mathrm{~m}$, where tall buildings could fit. Their location is determined largely by the island hills scattered within the urbanized part of the city, particularly in the peripheral areas of the main city core.

The scenic absorptivity of Jelenia Góra city based on the digital elevation model is shown in Figure 18a. The overall spatial distribution of most notable areas did not change significantly compared to the results of the analysis performed using the DSM. On the other hand, all the small scenic absorptivity areas obtained from land cover elements, mainly buildings, disappeared. Figure $18 \mathrm{~b}$ shows the absolute change in the scenic absorptivity scale after considering the land cover for the analysis.

The greatest changes in the magnitude of the scenic absorptivity scale in the research area are visible in the Karkonosze Foothills and the western Bóbr River Valley. These are changes due to the inclusion of forest areas within the model in mountains and hills. This indicates the highly notable impact of mountain forest cover on the scenic absorptivity of the region. Generally, all land cover features have a significant impact on the scenic absorptivity value of the area. The greater the number of elements, such as high forest walls or dense tall buildings, the greater the number of new elements that can be added to a landscape. 


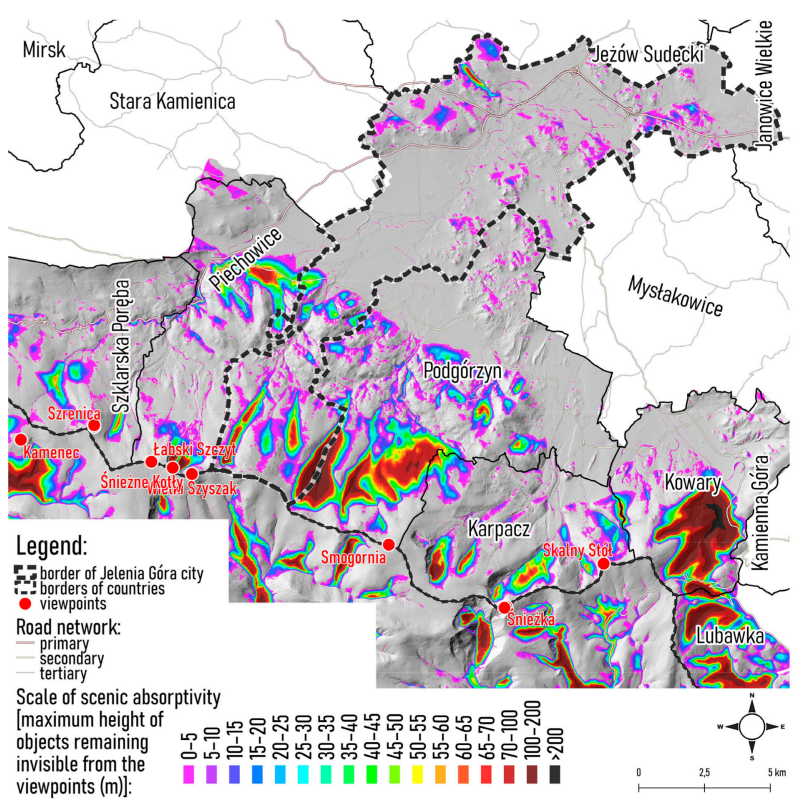

(a)

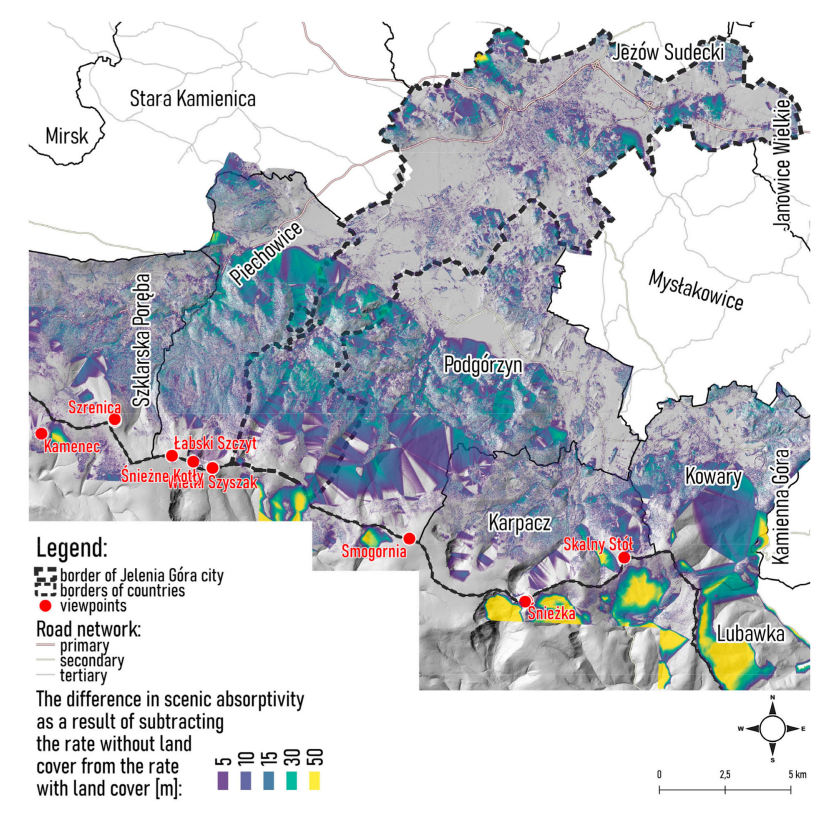

(b)

Figure 18. (a) Scenic absorptivity of Jelenia Góra city based on digital elevation model; (b) the difference in scenic absorptivity as a result of subtracting the rate without land cover elements from the rate with land cover entities.

The results of overlaying scenic absorptivity on the map of the development directions contained in the study of conditions and directions of land development of Jelenia Góra city are shown in Figure 19.

In the system of spatial planning in Poland, there are rules regarding the possibility of carrying out residential development based on the issuance of a building permit. This permit is issued on the basis of a document called the land development plan, which in turn must be consistent with the document called the study of conditions and directions of land development. Such an arrangement, at least in theory, ensures that the regulations set forth in the study of conditions and directions of land development regarding, for example, the development of housing, will be enforced. Among the key factors that can rapidly contribute to the degradation of the natural landscape is development. This arrangement causes planning documents, such as the study of conditions and directions of land development, to have a pivotal influence on landscape transformation.

In the city space, the most significant areas of scenic absorptivity are located in areas designated for greenery or agricultural use, particularly in the southern part of the area. It is understandable that due to numerous forms of nature protection in this place and difficulties in construction investments related to the land configuration, no development will be built in these areas. Similarly, in the western part of the Bóbr River Valley, the hills that the river crosses at this location effectively prevent development, due to the high number of slopes. The most favorable locations for development within the city area are located in the flattened central belt. Here, between agricultural lands, the document (study of conditions and directions of land development) enables residential development. As shown in Figure 19, there are several areas designated for residential development, the realization of which would not adversely affect the local landscape. Figure 19a indicates a group of areas of significant scenic absorptivity, reaching above $50 \mathrm{~m}$, which are located partially in single-family and multi-family residential areas. In areas of this kind, it would be possible to realize high buildings that would not affect the landscape values of the city perceived from the Karkonosze Mountains. Scenic absorptivity at this location is provided by the Sołtysia Hill. Figure 19b indicates areas of high scenic absorptivity, provided by elevated lands, located in both single-family residential and commercial areas. This arrangement indicates that in these service areas, it would be possible to build, 
for example, a large shopping mall, which would not affect the value of the landscape observed from the Karkonosze Mountains. In the vicinity of Maciejowa (Figure 19c,d), there are zones of significant scenic absorptivity located in the areas designated in the document for residential and service functions. Such an arrangement, together with the close proximity of an important communication artery, makes it possible to locate, for example, a group of high-rise office buildings that would not adversely affect the local landscape. Similarly, in the case of Goduszyn (Figure 19e), the area in which the document assumes the development of residential and service lands, there are areas of significant scenic absorptivity. Here, they are also determined by the location of local elevations in the form of Komorzyca and Skalica Hills. Figure 19f shows areas of scenic absorptivity of considerable height, which are located in the areas designated in the document for industry. Such a situation would allow us to locate a warehouse or another hall in this place, which would not have a negative impact on the landscape of Jelenia Góra city. There are many more examples of this type, resulting from the spatial distribution of scenic absorptivity together with the distribution of land use types included in the document. Only a few areas have been indicated in order to show the wide possibilities of using scenic absorptivity in the study of landscape threats posed by spatial planning documents. Unfortunately, in Jelenia Góra city, most of the areas intended for development are located outside the scenic absorptivity areas, which, if invested in, in accordance with the intended purpose, can have a negative impact on the landscape of Jelenia Góra city perceived from the Karkonosze Mountains.

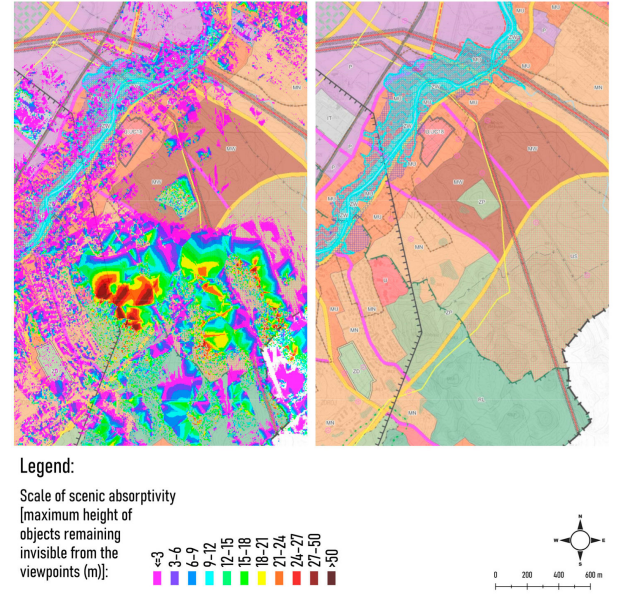

(a)

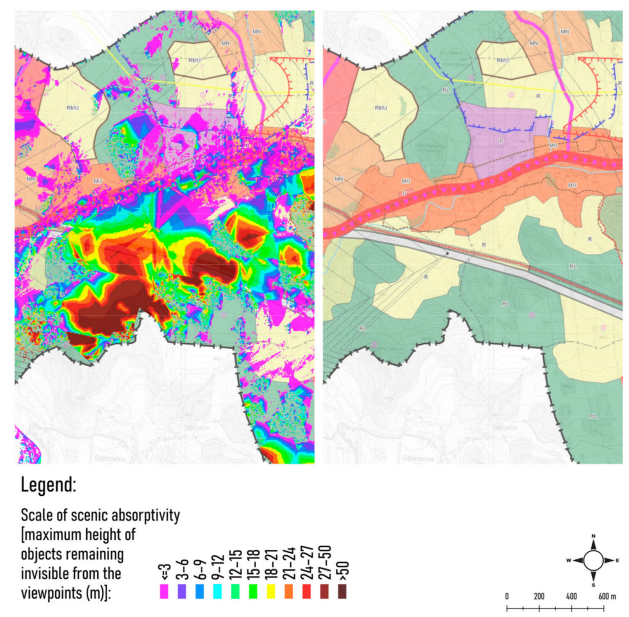

(c)

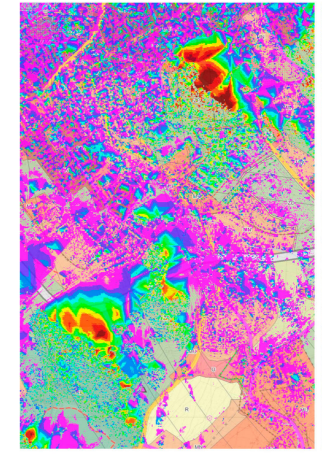

Legend:

Scale of scenic absorptivity
[maximum height of

Imaximum height
objects remaining

invisible from the
viewpoints $(\mathrm{m})]$ :

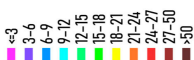
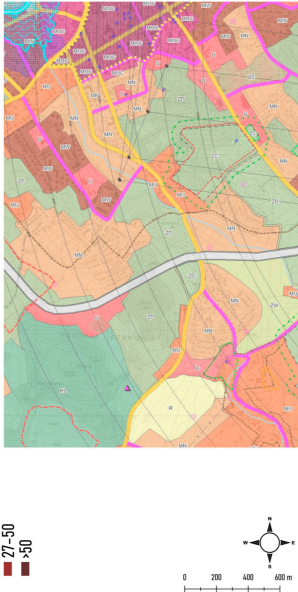

(b)

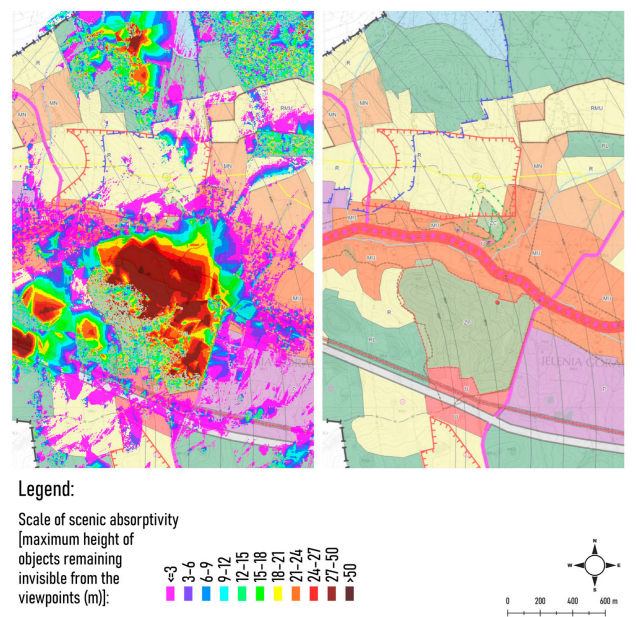

(d)

Figure 19. Cont. 


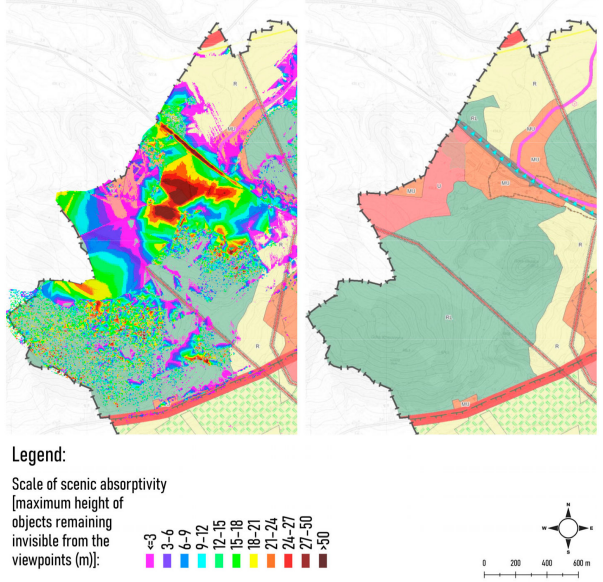

(e)

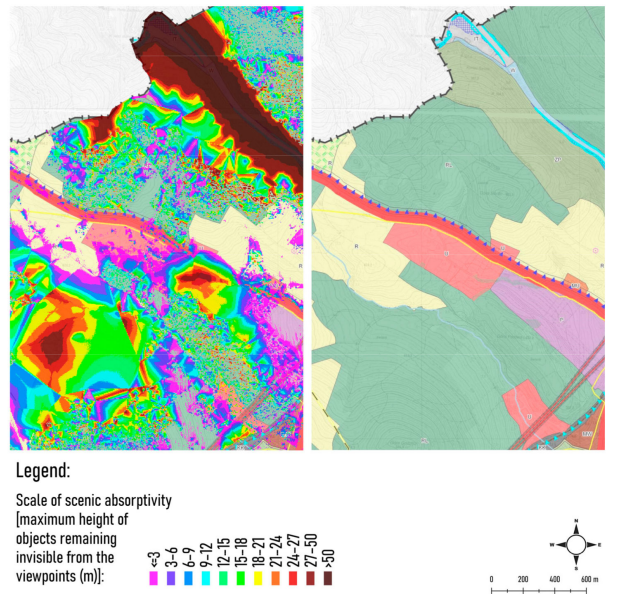

(f)

Figure 19. Results of overlaying scenic absorptivity on areas designated for development in the map of the development directions contained in the study of conditions and directions of land development of Jelenia Góra city, by area: (a) near the village of Staniszów; (b) near Kościuszki Hill; (c) Grabary; (d) Maciejowa; (e) Goduszyn; (f) near Jana Sobieskiego street.

\section{Discussion}

4.1. The Character of the Landscape and the Influence of Relief and Land Cover on the Spatial Distribution of Landscape Units of Jelenia Góra City

In recent years, the TPI is commonly used in geomorphology to classify landforms [34,35,38-42]. In this paper, landforms analysis was used as a factor indicating the character of the city landscape. Another factor that was considered was the spatial distribution of areas with different land cover based on Urban Atlas spatial data. Combining these methods to describe landscape character has not been attempted previously, so the proposed method fills a gap in the research using geomorphological information in landscape studies. In the past, attempts have been made to objectify the description of landscape character [22]. The research methods indicated in this article are supplementary to these attempts, as they allow us to generate a landform map automatically, using only altitude information.

An issue that requires special attention in the Point Bonitation Method is the appropriate selection of attributes used during the valorization process [43]. The most common factors used in this method include land elevation assessment [44], forest shoreline length assessment, surface water shoreline length assessment [45], land cover type and its diversity [46-49], and specific anthropogenic objects not included in any land cover type [50]. No attempt has been made to date to include information on the diversity of landforms based on the TPI in the landscape criteria of the Point Bonitation method.

4.2. The Capacity to Accept New Elements into the Landscape of Jelenia Góra City without Losing Its Value and the Impact of Land Cover Features on This Ability

The pioneering publication on landscape absorptive capacity studies was proposed by Jacobs and Way in 1969. The authors developed criteria for evaluating the ability of a landscape to absorb different levels and types of changes resulting from development by analyzing landform, land cover, and visibility and defining landscape absorptivity as the visual absorption capacity (VAC) factor [51]. The next step in developing the landscape absorptivity method was to define VAC as the ability of a landscape to accept changes in development without visibly affecting its character, and to examine the influence of landscape elements and features on this factor [52]. The results of the study found that slope, landscape complexity, soil color, and type and height of vegetation had the greatest impact on VAC, which was then used to illustrate the ability of the landscape to absorb change by three categories: high, medium, and low [52]. This research has been previously used 
for forest landscape studies. An analysis of the impact of transportation system expansion on landscape quality is considered to be the first attempt to use the developed assessment method for other purposes [53]. The following years saw a significant development in the VAC method. In 1979, two approaches to its use were proposed. The first one consisted of defining three groups of factors influencing the value of the index-biophysical factors (e.g., slope, vegetation variation, and soil color variation), perceptual factors (e.g., observer's position and distance), and factors connected with the type and surface of the assessed element. The VAC index was derived by summing the point values awarded for selected factors [54]. The second approach identified a factor affecting the ability of a development to hide in the landscape, in terms of the degree of visual penetration of the area observed from the adopted point, which is influenced by topographic conditions, vegetation cover, complexity of landscape composition, variation in color, and other landscape forms. The result was supposed to indicate the possibility of hiding the planned element in green structures [55]. In the 1990s, landscape capacity studies were undertaken as part of the Landscape Character Assessment-the basis for landscape management in the United Kingdom and Scotland. In 2002, the Landscape Character Assessment-Guidelines for The United Kingdom and Scotland was produced, which defined landscape capacity in one of its appendices as the degree to which a landscape type is able to accommodate change without significantly affecting its character [56]. In this case, the process of determining landscape capacity was significantly expanded. It was indicated that the process of assessing landscape capacity is based on an analysis of natural, cultural, and visual factors. The value of landscape capacity was determined using a matrix of values divided into three categories: high, medium, and low. The result was a compilation of the landscape sensitivity and value assessment conducted earlier.

In subsequent years, the topic of landscape absorptive capacity was also approached in the context of visual aspects alone, ignoring soil properties, vegetation regeneration potential, vegetation diversity, and slope relative to the view. Such a perspective on the problem was presented by Ozimek, who based it on DTM data and visibility field analyses [57]. The main change in our approach was to generate an upper bound for the invisible space from the assumed viewpoints based on the TIN model. This change allowed us to accurately determine the height of the invisible space relative to the terrain. Another development of the method was to analyze the influence of land cover elements on scenic absorptivity.

Considering previous methods of landscape absorptivity studies, the results presented in this article show the great improvement in GIS tools and the increasing availability of geomorphometric data. The accuracy and completeness of the DTM data also ensure the objectivity of the results. Analyses of the DTM data in the GIS environment allow us to study areas of any size, taking into account any number of observation points in the context of the possibility of adopting new elements without losing the value of the landscape. Theoretically, the method indicated in this paper allows, first of all, a very fast and efficient scenic absorptivity analysis for any large area and any number of viewpoints, thanks to DTM data. Therefore, it can be concluded that the presented method is an important development of research in landscape capacity and the influence of land cover elements on the landscape.

\subsection{Usefulness of DTM Data in Landscape Researches}

The compiled research demonstrates the great applicability of the GIS environment and geomorphometric data in landscape research. This article presents new methods for the use of DTM data in landscape research, which develop, improve, and provide a different perspective on the methods undertaken to date. Both in the case of scenic absorptivity analysis and character of the landscape analysis, the terrain model with $1 \mathrm{~m}$ resolution allowed us to obtain sufficiently detailed results for landscape studies at the urban scale. 


\subsection{Further Research Directions}

Both the scenic absorptivity analysis as well as the landscape characterization analysis with a focus on the diversity of landforms are among the many analytical applications of DTM data. In practice, there are many research and application fields where these data and the analyses performed in this article can be used. These include, in particular, elements directly based on the methods described:

- Assessment of landscape unit dissimilarity based on the method of describing landscape characteristics and the diversity of landforms and land cover classes;

- Determination of landscape type models based on the method of describing landscape characteristics based on the diversity of landforms and land cover classes;

- Supporting the processes of aesthetic value assessment and landscape valorization using landscape characterization analysis based on the diversity of landforms;

- Studies of landscape change based on changes in the scenic absorptivity, using DSM data from different time periods;

- Scenic absorptivity studies for different types of landscape, particularly in the distribution of the natural and transformed landscapes;

- Studies of the maximum volume of buildings that would not degrade the mountain landscape, based on scenic absorptivity volume;

- Support studies of the conservation and threat status of landscapes using the scenic absorptivity method.

\section{Conclusions}

This paper proposes two methods for using DTM data in landscape research. The first was to identify a set of components of the Jelenia Góra city landscape character on the basis of the topographic position index and the spatial distribution of land cover, while the second was to use DEM and DSM data to assess the landscape of Jelenia Góra city in terms of the possibility of adopting new elements, using methods to evaluate visual aspects of scenic absorptivity. The analyses carried out allowed us to obtain results that helped to find answers to the research questions posed.

1. The landscape of Jelenia Góra city consists mainly of forest areas with a considerable diversity of landforms, as well as agricultural areas with low geomorphological diversity and urbanized areas also mostly with low diversity in terms of variety of landforms. Forested areas are the most geomorphologically diverse, followed by urbanized areas and agricultural lands. In the three studied land cover groups, only forested areas are characterized by the domination of areas with medium landform diversity. Agricultural lands and urbanized areas are dominated by low landform diversity.

2. Based on synthesizing the spatial distribution of land cover and the diversity of landforms, 10 spatial units distinct from these factors were identified. In the assessment of these two factors, it was observed that this allows us to clearly define the boundaries of homogeneous areas. On the basis of these two factors only, it was possible to distinguish, among others, the Karkonosze Mountains, Izera Foothills, Łomnickie hills, Cieplice depression, Maciejowa, and the urban core of Jelenia Góra city. Within areas that are homogeneous in terms of relief, the inclusion of land cover brought out further landscape variations. Similarly, in the case of areas homogeneous in terms of land cover, landform diversity made it possible to indicate differences in the character of these areas. Taking into account and combining these two factors allowed not only the delimitation of landscape units included in the study of conditions and directions of land development of Jelenia Góra city, but also its more precise division.

3. The results of the assessment of the landscape of Jelenia Góra city in terms of the possibility of adopting new elements presented in this article show that there are areas within the city that are able to accept new buildings without losing the value of the landscape. However, most areas of the city are visible from adopted landscape vantage points, indicating that areas lacking scenic absorptivity outweigh areas capable of 
accepting new elements into the landscape. The identified areas of scenic absorptivity are mostly determined by the location of the terrain elevations. In the mountainous southern area, these are valley areas, while in the urbanized area, these are areas located north of the hills.

4. It has been proven that there are areas of scenic absorptivity in the research area, which are also provided for the development in the study of conditions and directions of land development. Nevertheless, most of the areas planned for development in the document are located in visible places from important landscape observation points, which can result in potential negative impacts on the landscape perceived from these points. This situation indicates the existence of a threat to the landscape of Jelenia Góra city resulting from the planned development.

5. The results of the analyses indicate a significant influence of forest areas on the scenic absorptivity of the city, which is synonymous with its influence on hiding landscape changes perceived from the adopted viewpoints. This is particularly true in the areas of hills and knolls located in the northern part of the city. This result confirms the importance of the protection of forest sites in the area of Jelenia Gora city in the context of the prevention of landscape degradation. Existing development does not affect scenic absorptivity as much as forested areas. Rather, its character determines individual areas hidden directly in the view shadow of single buildings.

6. The $1 \mathrm{~m}$ resolution digital terrain model data acquired for this study, consisting of both a digital elevation model and a digital situation model, allowed us to comprehensively perform the established methodological steps. In the context of the conducted research, by using DTM data, highly accurate results were obtained. At the same time, many opportunities for the development of the conducted research were identified, which further emphasizes the value of these data.

Both the tools implemented in the GIS environment as well as the DTM data allow a significantly improvement in landscape studies. With the ever-increasing computational capabilities of computers to analyze increasingly accurate terrain data in detail, computerassisted landscape analysis can be developed more rapidly. The analyses conducted in this paper, based on the accurate DTM, prove the great improvement in the context of landscape research that these data provide.

Author Contributions: Conceptualization, P.K. and G.B.; methodology, G.B.; software, G.B.; validation, P.K.; formal analysis, P.K.; resources, G.B.; data curation, G.B.; writing-original draft preparation, G.B.; writing-review and editing, P.K.; visualization, G.B.; supervision, P.K.; project administration, P.K.; funding acquisition, P.K. All authors have read and agreed to the published version of the manuscript.

Funding: This research was funded by the National Science Centre, Poland, grant number 2018/31 /D/HS4/00659.

Institutional Review Board Statement: Not applicable.

Informed Consent Statement: Not applicable.

Data Availability Statement: Publicly available datasets were analyzed in this study. This data can be found here: https:/ / mapy.geoportal.gov.pl/imap/Imgp_2.html, https://land.copernicus.eu/ local/urban-atlas/urban-atlas-2018, accessed on 15 July 2021.

Conflicts of Interest: The authors declare no conflict of interest.

\section{References}

1. Gaździcki, J. Systemy Informacji Przestrzennej; Państwowe Przedsiębiorstwo Wydawnictw Kartograficznych im. Eugeniusza Romera: Warszawa, Poland, 1990.

2. Geomatyka w Lasach Państwowych. Available online: https://www.geomatyka.lasy.gov.pl/numeryczny-model-terenu (accessed on 29 May 2021).

3. Kozioł. K.; Knecht. J.; Szombara. S. Znaczenie hierarchii w generalizacji Numerycznego Modelu Terenu. Geomatyka i Inżynieria 2012, 2, 58-72. 
4. Weibel, R.; Heller, M. Digital Terrain Modeling. In Geographical Information Systems; Maguire, D., Goodchild, M., Rhind, D., Eds.; Longman Scientific and Technical: London, UK, 1991; pp. 269-297.

5. Li, Z.; Zhu, Q.; Gold, C. Digital Terrain Modeling_Principles and Methodology; CRC Press: Boca Raton, FL, USA, 2005 ; p. 324.

6. Pike, R.J.; Evans, I.S.; Hengl, T. Geomorphometry: A Brief Guide. Dev. Soil Sci. 2009, 33, 3-30.

7. Burrough, P.A. Principles of Geographical Information Systems for Land Resources Assessment. In Methods of Interpolation; OUP: Oxford, UK, 1986; Volume 8, pp. 147-166.

8. Kemp, K. Encyclopedia of Geographic Information Science; SAGE Publications: Los Angeles, CA, USA, 2008 ; p. 582.

9. Shary, P.A. Models of topography. In Advances in Digital Terrain Analysis; Zhou, Q., Lees, B., Tang, G., Eds.; Springer: Berlin, Germany, 2008; pp. 29-58.

10. Weng, Q. Remote Sensing and GIS Integration: Theories, Methods, and Applications; McGraw-Hill: New York, NY, USA, $2010 ;$ p. 433.

11. Vterrain. Available online: http:/ / www.vterrain.org/Elevation/ (accessed on 28 May 2021).

12. Czajka, W. Baza danych wysokości terenu w formacie DTED. Bellona 2009, 3, 26-30.

13. Evans, A.J.; Russel, D.C. Utilising the ordnance survey national GPS network for digital surface modelling. Surv. Rev. 2013, 37, 411-417. [CrossRef]

14. Polskie Towarzystwo Informacji Przestrzennej (Polish Association for Spatial Information). Available online: http:/ / www.ptip. org.pl/ (accessed on 28 May 2021).

15. Gołuch, P. Numeryczny model terenu, numeryczny model pokrycia terenu i ortofototomapa jako źródło danych dla przeprowadzenia modelowania hydrodynamicznego. Arch. Fotogram. Kartogr. Teledetekcji 2003, 13 B, 361-370.

16. Zhang, W.; Montgomery, D.R. Digital elevation model grid size, landscape representation, and hydrologic simulations. Water Resour. Res. 1994, 30, 1019-1028. [CrossRef]

17. Magalhaes, M.A.; Magalhaes, S.V.G.; Alvim Andrade, M.V.; Lisboa Filho, J. An efficient algorithm to compute the viewshed on DEM terrains stored in the external memory. In Proceedings of the IX Brazilian Symposium on Geoinformatics, São Paulo, Brazil, 25-28 November 2007; pp. 183-194.

18. Taborton, D. A new method for the determination of flow directions and upslope areas in grid digital elevation models. Water Resour. Res. 1997, 33, 309-319.

19. Badura, J.; Przybylski, B. Application of digital elevation models to geological and geomorphological studies-Some examples. Przeglad Geologiczny 2005, 53, 977-983.

20. Fryśkowska, A. Analiza możliwości wykorzystania danych z lotniczego skaningu laserowego do opracowywania trójwymiarowych modeli miast. Biuletyn WAT 2011, 60, 262-276.

21. Webster, T.L.; Murphy, J.B.; Gosse, J.C.; Spooner, I. The application of lidar-derived digital elevation model analysis to geological mapping: An example from the Fundy Basin, Nova Scotia, Canada. Can. J. Remote Sens. 2006, 32, 173-193. [CrossRef]

22. Nita, J. Wykorzystanie numerycznych modeli powierzchni terenu i zdjęć lotniczych w ocenie form morfologicznych dla potrzeb waloryzacji krajobrazu. Arch. Fotogram. Kartogr. Teledetekcji 2002, 12, $275-281$.

23. Washtell, J.; Carver, S.; Arrell, K. A viewshed based classification of landscapes using geomorphometrics. In Proceedings of the Geomorphometry, Zurich, Switzerland, 31 August-2 September 2009; pp. 44-49.

24. Krajewski, P.; Solecka, I.; Mrozik, K. Forest Landscape Change and Preliminary Study on Its Driving Forces in Ślęża Landscape Park (Southwestern Poland) in 1883-2013. Sustainability 2018, 10, 4526. [CrossRef]

25. Wu, W.; Fan, Y.; Wang, Z.; Liu, H. Assessing effects of digital elevation model resolutions on soil-landscape correlations in a hilly area. Agric. Ecosyst. Environ. 2008, 126, 209-216. [CrossRef]

26. Khromykh, W.; Khromykh, O. Analysis of Spatial Structure and Dynamics of Tom Valley Landscapes based on GIS, Digital Elevation Model and Remote Sensing. Procedia Soc. Behav. Sci. 2014, 120, 811-815. [CrossRef]

27. Luo, W.; Mao, L.; Liu, B. Application of ASTER DEM in the Investigation of Tourism Resources and Environment. In Proceedings of the 2013 International Conference on Computer Sciences and Applications, Wuhan, China, 14-15 December 2013.

28. Florinsky, I.V. Combined analysis of digital terrain models and remotely sensed data in landscape investigations. Prog. Phys. Geogr. Earth Environ. 1998, 22, 33-60. [CrossRef]

29. Kościuk, J.; Ćmielewski, B. LiDAR i Dron w Badaniach Środowiskowych, Urbanistycznych i Architektoniczno-Archeologicznych; Laboratorium Skanowania i Modelowania 3D oraz Centrum Badań Andyjskich Uniwersytetu Warszawskiego: Warsaw, Poland, 2021.

30. Florinsky, I.V.; Kuryakova, G.A. Determination of grid size for digital terrain modelling in landscape investigations-exemplified by soil moisture distribution at a micro-scale. Int. J. Geogr. Inf. Sci. 2000, 14, 815-832. [CrossRef]

31. Scialert. Available online: https:/ / scialert.net/fulltext/?doi=jas.2008.910.921 (accessed on 31 March 2021).

32. Geoportal Krajowy. Available online: https://mapy.geoportal.gov.pl/imap/Imgp_2.html (accessed on 21 October 2020).

33. Land Copernicus. Available online: https://land.copernicus.eu/local/urban-atlas (accessed on 21 October 2020).

34. Weiss, A.D. Topographic Position and Landforms Analysis. 2001. Available online: http://www.jennessent.com/downloads/tpiposter-tnc_18x22.pdf (accessed on 31 March 2021).

35. Mokarram, M.; Hojati, M. Comparison of Landform Classifications of Elevation, Slope, Relief and Curvature with Topographic Position Index in the South of Bojnoord. Ecopersia 2016, 4, 1343-1357. [CrossRef]

36. Warszyńska, J. Waloryzacja miejscowości z punktu widzenia atrakcyjności turystycznej. Prace Geograficzne UJ $1971,49,14-35$.

37. Mokarram, M.; Roshan, G.; Negahban, S. Landform classification using topography position index (case study: Salt dome of Korsia-Darab plain, Iran). Model. Earth Syst. Environ. 2015, 1, 40. [CrossRef] 
38. Chabala, L.M. Landform classification for digital soil mapping in the Chongwe-Rufunsa area, Zambia. Agric. For. Fish. 2013, 2, 156-160. [CrossRef]

39. Muddarisma, N.; Yuniwati, E.D.; Masruroh, H.; Oktaviansyah, A.R. An Automated Approach Using Topographic Position Index (TPI) for Landform Mapping (Case Study: Gede Watershed, Malang Regency, East Java, Indonesia). In Proceedings of the 2nd International Conference on Geography and Education, East Java, Indonesia, 10 October 2019; Volume 412, pp. 1-6.

40. De Reu, J.; Bourgeois, J.; Bats, M.; Zwertvaegher, A.; Gelorini, V.; De Smedt, P.; Chu, W.; Antrop, M.; De Maeyer, P.; Finke, P.; et al. Application of the topographic position index to heterogeneous landscapes. Geomorphology 2013, 186, 39-49.

41. Jiang, L.; Ling, D.; Zhao, M.; Wang, C.; Liang, Q.; Liu, K. Effective Identification of Terrain Positions from Gridded DEM Data Using Multimodal Classification Integration. Int. J. GeoInf. 2018, 7, 443.

42. Seif, A. Using Topography Position Index for Landform Classification (Case study: Grain Mountain). Bull. Environ. Pharmacol. Life Sci. 2014, 3, 33-39.

43. Galiński, M.; Siwek, G.; Szuwarski, J. Metoda bonitacji punktowej jako narzędzie waloryzacji przestrzennych [The Point Bonitation Method as a Tool of Spatial Valorization]. Geomatyka Inżynieria Kwart. Nuakowy 2016, 2, 5-19.

44. Richling, A.; Solon, J. Ekologia Krajobrazu; PWN: Warsaw, Poland, 2011; pp. 189-196.

45. Kent, R.L.; Elliot, C.L. Scenic routes linking and protecting natural and cultural landscape features: A greenway skeleton. Landsc. Urban Plan. 1995, 33, 341-355.

46. Śleszyński, P. Nowa metoda oceny atrakcyjności wizualnej krajobrazu. Problemy Ekologii Krajobrazu 1999, 5, 37-55.

47. Solecka, I.; Raszka, B.; Krajewski, P. Landscape analysis for sustainable land use policy: A case study in the municipality of Popielów, Poland. Land Use Policy 2018, 75, 116-126. [CrossRef]

48. Krajewski, P. Monitoring of Landscape Transformations within Landscape Parks in Poland in the 21st Century. Sustainability 2019, 11, 2410. [CrossRef]

49. Tokarczyk-Dorociak, K.; Kazak, J.; Szewrański, S. Delimitacja jednostek krajobrazowych w celu wstępnej identyfikacji krajobrazów strefy podmiejskiej Wrocławia. Infrastrukt. Ekologia Terenów Wiejskich 2017, Nr I/2, 371-384.

50. Jakiel, M. Ocena atrakcyjności wizualnej krajobrazu dolinek krakowskich-Możliwości zastosowania w planowaniu przestrzennym. Wspótczesne Problemy Kierunki Badawcze Geografii 2015, 3, 91-107.

51. Jacobs, P.; Way, D. How much development can landscape absorb? Landsc. Archit. 1969, 58, 70-72.

52. Knode, J. Landscape Management Survey, Northwest Kuiu Island; USDA Forest Service: Juneau, AK, USA, 1998.

53. Johnson, C.G. Mineral King Visual Analysis; U.S. Forest Service: San Francisco, CA, USA, 1974.

54. Anderson, L.; Mosier, J.; Chandler, G. Visual Absorption Capability. In Our National Landscape—A Conference on Applied Techniques for Analysis and Management of the Visual Resource 23-25 April 1979, Incline Village, Nevada; Elsner, G., Smardon, R., Eds.; Pacific Southwest Forest and Range Exp. Station: Berkeley, CA, USA, 1979; pp. 164-172.

55. Yeomans, W.C. A proposed biophysical approach to Visual Absorption Capability (VAC). In Our National Landscape-A Conference on Applied Techniques for Analysis and Management of the Visual Resource 23-25 April 1979, Incline Village, Nevada; Elsner, G., Smardon, R., Eds.; Pacific Southwest Forest and Range Exp. Station: Berkeley, CA, USA, 1979; pp. 172-182.

56. Swanwick, C. Techniques and criteria for judging capacity and sensitivity. Available online: https://www.adur-worthing.gov. uk/media/Media,139366,smxx.pdf (accessed on 31 March 2021).

57. Ozimek, A.; Ozimek, I. Computer-Aided Method of Visual Absorption Capacity Estimation. In Digital Design in Landscape Architecture; Wichmann Verlag: Heidelberg, Germany, 2008; pp. 105-114. 